\title{
Global Proteomics to Study Silica Nanoparticle-Induced Cytotoxicity and Its Mechanisms in HepG2 Cells
}

\author{
Sun Young Lee ${ }^{1} \mathbb{D}$, In Young Kim ${ }^{2}$, Min Beom Heo ${ }^{2}$, Jeong Hee Moon ${ }^{3}$, Jin Gyeong Son ${ }^{1, *}$ and Tae Geol Lee ${ }^{1, *}$ \\ 1 Bioimaging Team, Safety Measurement Institute, Korea Research Institute of Standards and Science (KRISS), \\ Daejeon 34113, Korea; sylee12@kriss.re.kr \\ 2 Nano-Safety Team, Safety Measurement Institute, Korea Research Institute of Standards and Science (KRISS), \\ Daejeon 34113, Korea; inyoungkim@kriss.re.kr (I.Y.K.); mbheo@kriss.re.kr (M.B.H.) \\ 3 Disease Target Structure Research Center, Korea Research Institute of Bioscience and Biotechnology (KRIBB), \\ Daejeon 34141, Korea; jhdal@kribb.re.kr \\ * Correspondence: yeskyoung@kriss.re.kr (J.G.S.); tglee@kriss.re.kr (T.G.L.); \\ Tel.: +82-42-868-5751 (J.G.S.); +82-42-868-5003 (T.G.L.)
}

check for updates

Citation: Lee, S.Y.; Kim, I.Y.; Heo, M.B.; Moon, J.H.; Son, J.G.; Lee, T.G. Global Proteomics to Study Silica Nanoparticle-Induced Cytotoxicity and Its Mechanisms in HepG2 Cells. Biomolecules 2021, 11, 375. https:// doi.org/10.3390/biom11030375

Academic Editor: Simona Clichici

Received: 20 January 2021

Accepted: 24 February 2021

Published: 2 March 2021

Publisher's Note: MDPI stays neutral with regard to jurisdictional claims in published maps and institutional affiliations.

Copyright: (c) 2021 by the authors. Licensee MDPI, Basel, Switzerland. This article is an open access article distributed under the terms and conditions of the Creative Commons Attribution (CC BY) license (https:/ / creativecommons.org/licenses/by/ $4.0 /)$.

\begin{abstract}
Silica nanoparticles ( $\left.\mathrm{SiO}_{2} \mathrm{NPs}\right)$ are commonly used in medical and pharmaceutical fields. Research into the cytotoxicity and overall proteomic changes occurring during initial exposure to $\mathrm{SiO}_{2} \mathrm{NPs}$ is limited. We investigated the mechanism of toxicity in human liver cells according to exposure time $[0,4,10$, and $16 \mathrm{~h}(\mathrm{~h})]$ to $\mathrm{SiO}_{2} \mathrm{NPs}$ through proteomic analysis using mass spectrometry. $\mathrm{SiO}_{2} \mathrm{NP}$-induced cytotoxicity through various pathways in HepG2 cells. Interestingly, when cells were exposed to $\mathrm{SiO}_{2} \mathrm{NPs}$ for $4 \mathrm{~h}$, the morphology of the cells remained intact, while the expression of proteins involved in mRNA splicing, cell cycle, and mitochondrial function was significantly downregulated. These results show that the toxicity of the nanoparticles affects protein expression even if there is no change in cell morphology at the beginning of exposure to $\mathrm{SiO}_{2} \mathrm{NPs}_{\text {. The }}$ levels of reactive oxygen species changed significantly after $10 \mathrm{~h}$ of exposure to $\mathrm{SiO}_{2} \mathrm{NPs}$, and the expression of proteins associated with oxidative phosphorylation, as well as the immune system, was upregulated. Eventually, these changes in protein expression induced HepG2 cell death. This study provides insights into cytotoxicity evaluation at early stages of exposure to $\mathrm{SiO}_{2} \mathrm{NPs}$ through in vitro experiments.
\end{abstract}

Keywords: silica nanoparticles; cytotoxicity; label-free quantification; proteomic analysis; mass spectrometry

\section{Introduction}

Silica nanoparticles ( $\mathrm{SiO}_{2} \mathrm{NPs}$ ) are popular materials used in drug delivery and various bio-applications due to their excellent bio-stability, easy surface modification, and ability for fluorescent tagging [1-3]. In addition, $\mathrm{SiO}_{2} \mathrm{NPs}$ are widely used in numerous industries, and can affect people through various routes depending on the manufacturing process [4]. In particular, the enhanced potential for human exposure to engineered $\mathrm{SiO}_{2}$ NPs through ingestion, inhalation, or dermal penetration due to their increased prevalence in commercial applications is an important concern [5]. Increasing exposure concerns in the industrial sector have raised global concerns about the safety and potential health impacts of $\mathrm{SiO}_{2}$ NPs. According to the Nanomaterials Health Implications Research (NHIR) Consortium, run by the U.S. National Institutes of Environmental Health Sciences, there are three directions for toxicity studies: physicochemical characteristics, in vitro assays (cellular and non-cellular), and in vivo assays [6]. The physicochemical properties of nanoparticles, which were overlooked at the beginning of their toxicity studies, are likely to influence toxicity results. Physicochemical properties, such as particle size and size distribution, agglomeration state, shape, crystal structure, chemical composition, and surface area, could affect the cell and animal responses $[7,8]$. In general, the smaller size of nanoparticles and 
more pores on the surface result in higher cytotoxicity $[9,10] . \mathrm{SiO}_{2} \mathrm{NPs}$ of $50 \mathrm{~nm}$ or smaller depending on the treatment time or the presence or absence of serum, but at concentrations above $25 \mu \mathrm{g} / \mathrm{mL}$, they generally begin to exhibit cytotoxicity [11,12]. When modifying the cell surface, different types of modification ligands can exert different effects in vitro and in vivo. In the case of $\mathrm{SiO}_{2} \mathrm{NPs}$ produced by the flame synthesis method, which is widely used in the industrial sector, the higher the amount of surface silanol groups, the lower the toxicity shown [13]. In the case of $70 \mathrm{~nm} \mathrm{SiO} 2 \mathrm{NPs}$, unmodified $\mathrm{SiO}_{2} \mathrm{NPs}_{2}$ entered near the nucleus more effectively than those modified with amine or carboxyl, and exhibited higher toxicity [14]. Recent studies have shown that cationic nanoparticles induce greater cytotoxicity compared to anionic nanoparticles [15-17]. Physicochemical characteristics are an important consideration for assessing toxicity. The confounding effects of poor sample characterization on determining the causes of toxicity necessitates high-quality preparation of nanomaterials for analysis.

$\mathrm{SiO}_{2} \mathrm{NPs}$ have been subjected to investigations of their biological safety through various methods both in vivo and in vitro. In vivo studies with $\mathrm{SiO}_{2} \mathrm{NP}$-treated mice demonstrated the particles were distributed in nearly all organs, and mainly accumulated and induced adverse effects in the lung, spleen, and liver [18-20]. The liver is a major organ in detoxification and is well known as a primary target organ for nanoparticles [21]. A recent study of acute exposure to $\mathrm{SiO}_{2}$ NPs by Sun et al. demonstrated that liver damage could be induced through macrophage infiltration and granuloma formation, while repeated exposure to $\mathrm{SiO}_{2} \mathrm{NPs}$ can induce liver fibrosis [22,23]. Many cell lines have been investigated through in vitro studies, and it was reported that excess exposure to $\mathrm{SiO}_{2}$ NPs could result in cytotoxic effects [24,25]. It has been shown that $\mathrm{SiO}_{2} \mathrm{NPs}$ can induce oxidative stress at 3 and $24 \mathrm{~h}$ post-treatment in vitro, suggesting that the oxidative stress-mediated mitochondrial pathway may lead to apoptosis, contributing to hepatotoxicity [26]. In addition, it has been reported that Kupffer cells can be activated by $\mathrm{SiO}_{2}$ NPs and contribute to hepatotoxicity by releasing bioactive mediators, such as tumor necrosis factor- $\alpha$, reactive oxygen species (ROS), and nitric oxide [27].

Research evaluating the biological activity and potential risks of nanomaterials has focused on the appropriate selection of biological endpoints [28-30]. Unfortunately, the primary focus of many cytotoxicity studies is limited to measuring the direct cytotoxic or pro-inflammatory effects of nanomaterials, rather than attention to subtle changes in biological function [31,32]. Evaluating the interaction of nanomaterials and cells is critical for safety considerations. In particular, mass spectrometry (MS)-based approaches are able to apply deep proteomics analysis for assessing protein adsorption on nanomaterials, proteomic changes, and cytotoxicity occurring when nanomaterials interact with the extracellular matrix through both in vitro and in vivo experiments [33]. Proteomics-based technology offers an attractive approach to both unbiased and multivariate systems analysis in evaluating nanomaterial and biological model interactions [34]. Recently, proteomic approaches have been used to evaluate the potential cytotoxicity of 11 different metal and metal oxide nanoparticles through quantitative cellular proteome profile studies [35]. In addition, the qualitative characterization of corona proteins on nanomaterials has become possible [36]. In the present study, we aimed to investigate the biological mechanisms underlying cell death following initial nanoparticle exposure using proteomics. As the proteome of the cell changes during the initial stage of exposure to nanoparticles, prior to the occurrence of any morphological changes, proteomic analysis based on MS was expected to provide insights into early changes underlying nanoparticle-induced cytotoxicity.

\section{Materials and Methods}

\subsection{Materials and Reagents}

For $20 \mathrm{~nm} \mathrm{SiO} 2$ NPs (301-01-002), the certified reference materials made by Korea Research Institute of Standards and Science were used. Tris-HCl buffer ( $\mathrm{pH}$ 8.0), phosphate buffered saline (PBS), sodium chloride $(\mathrm{NaCl})$, formic acid (FA), ammonium bicarbonate (AmBic), dithiothreitol (DTT), iodoacetamide (IAA), and L-cysteine were purchased from 
Sigma-Aldrich (St. Louis, MO, USA). Protease inhibitor cocktail were purchased from Roche Diagnostic GmbH (Mannheim, Germany). In order to digest the proteins, trypsin was purchased from Promega (Madison, WI, USA). HLB cartridge purchased from Waters (Milford, MA, USA) was used. Water (with 0.1\% FA), acetonitrile (ACN) (with $0.1 \%$ FA), n-dodecyl beta-D-maltoside (DDM), and bicinchoninic acid (BCA) protein assay reagent were purchased from Thermo Fisher Scientific (Rockford, IL, USA).

\subsection{Nanoparticles Characterization}

The shape and sizes on the surfaces of $\mathrm{SiO}_{2} \mathrm{NPs}$ were conducted by using transmission electron microscopy (TEM, TECNAI G2 F30 S-Twin), which was operated at $300 \mathrm{keV}$. The FT-IR spectrum was obtained using a Nicolet iS10 FT-IR spectrometer (Thermo Fisher Scientific) equipped with an attenuated total reflectance (ATR) accessory (Smart Miracle, PIKE Tech). One $\mu \mathrm{L}$ of $\mathrm{SiO}_{2}$ NPs solution was placed on a ZnSe-ATR crystal and dried under vacuum for $2 \mathrm{~h}$. The $\mathrm{HgCdTe}$ detector cooled by liquid $\mathrm{N}_{2}$ was used to collect the reflected light. A total of 16 scans were averaged to yield a spectrum at $4 \mathrm{~cm}^{-1}$ resolution. The average hydrodynamic size and distribution of the NPs in water were determined by using dynamic light scattering (DLS, Nano ZS90, Malvern Instruments Ltd., Worcestershire, UK). All measurements were conducted in disposable cuvettes and the samples were analyzed with a $4-\mathrm{mW}$ laser operating at a wavelength of $633 \mathrm{~nm}$ at $25^{\circ} \mathrm{C}$ and the scattering angle was fixed at $90^{\circ}$. The surface charge (zeta potential) of the NPs in water was detected by using an electrophoretic light scattering (ELS, Nano ZS90, Malvern Instruments Ltd., Worcestershire, UK). All samples were prepared by diluting the stock in deionized (DI) water. The operating temperature was kept constant at $25^{\circ} \mathrm{C}$.

\subsection{HepG2 Cell Culture and $\mathrm{SiO}_{2}$ NPs Treatment}

The HepG2 cells were purchased from the American Type Culture Collection (ATCC, Manassas, VA, USA) and maintained in Dulbecco's modified eagle's medium (DMEM) added with $10 \%$ fetal bovine serum (FBS) and 1\% penicillin-streptomycin (GIBCO-BRL, Grand Island, NY, USA). The cells were incubated in $5 \% \mathrm{CO}_{2}$ at $37^{\circ} \mathrm{C}$. For the treatment of cells, $\mathrm{SiO}_{2} \mathrm{NPs}$ were dispersed as $30 \mu \mathrm{g} / \mathrm{mL}$ concentration in a serum-free DMEM. The HepG2 cells were seeded and incubated for $24 \mathrm{~h}$. After the cells were washed with PBS, it was treated with prepared $\mathrm{SiO}_{2} \mathrm{NPs}$ for 4,10 , or $16 \mathrm{~h}$.

\subsection{Cell Viability Assay}

To evaluate the cell viability, we measured lactate dehydrogenase (LDH) release using CytoTox96 ${ }^{\circledR}$ Non-Radioactive Cytotoxicity Assay (Promega, Madison, WI, USA). After the cells were treated as indicated above, $100 \mu \mathrm{L}$ of supernatant was collected and tested according to the manufacturer's instructions.

\subsection{ROS Detection and Quantitation}

$\mathrm{SiO}_{2}$ NPs treated cells were washed in PBS and exposed $10 \mu \mathrm{M}$ CM- $\mathrm{H}_{2} \mathrm{DCF}-\mathrm{DA}$ (DCF) for $30 \mathrm{~min}$ at $37^{\circ} \mathrm{C}$. After washing again with PBS, the fluorescence of DCF was measured using a microplate reader.

\subsection{Sample Preparation for Proteomics}

In order to obtain the protein lysates from the HepG2 cells, $150 \mu \mathrm{L}$ of lysis buffer composing of $0.2 \% \mathrm{DDM}, 150 \mathrm{mM} \mathrm{NaCl}$, and one tablet of protease inhibitor cocktail in $50 \mathrm{mM}$ Tris- $\mathrm{HCl}$ solution was added to the cell pellets. The cell mixture was vortexed for $1 \mathrm{~min}$, and then incubated at $4{ }^{\circ} \mathrm{C}$ for $1 \mathrm{~min}$. The solution was centrifuged at $12,000 \times \mathrm{g}$ for $15 \mathrm{~min}$ at $4{ }^{\circ} \mathrm{C}$, the supernatants were transferred into new tubes for the isolation of proteins. The concentration of protein lysates was measured by using a BCA protein assay.

Twenty microgram of proteins was reduced by adding $50 \mathrm{mM}$ AmBic buffer containing $10 \mathrm{mM}$ DTT for $2 \mathrm{~h}$ at $37^{\circ} \mathrm{C}$, and were subsequently alkylated in the dark for $30 \mathrm{~min}$ at room temperature, after the addition of $20 \mathrm{mM}$ IAA solution. In order to remove the 
remaining IAA, $40 \mathrm{mM}$ L-cysteine was added and was allowed to incubate for $30 \mathrm{~min}$ at room temperature, followed by tryptic digestion of the samples (enzyme to substrate ratio of 1:20). The digestion was carried out overnight at $37^{\circ} \mathrm{C}$, and quenched with $5 \%$ FA. The digests were desalted by HLB cartridge and eluted with $0.5 \mathrm{~mL} \mathrm{H}_{2} \mathrm{O}: \mathrm{ACN}(50: 50, v / v)$ solution containing $0.1 \%$ FA. After evaporation, the peptides were stored at $-80{ }^{\circ} \mathrm{C}$ prior to nanoflow liquid chromatography-electrospray ionization-tandem mass spectrometry (nanoLC-ESI-MS/MS) analysis.

\subsection{Nanoflow Liquid Chromatography Tandem Mass Spectrometry}

The dried samples were reconstituted with $\mathrm{H}_{2} \mathrm{O}: \mathrm{ACN}(98: 2, v / v)$ solution containing $0.1 \% \mathrm{FA}$, and $500 \mathrm{ng}$ of peptide mixture was used for proteomic analysis. The peptide mixture was analyzed by using a NanoElute LC system connected to a hybrid trapped ion mobility spectrometry-quadrupole time-of-flight mass spectrometer (timsTOF Pro, Bruker Daltonics, Bremen, Germany), equipped with a modified nano-electrospray ion source (CaptiveSpray, Bruker Daltonics, Billerica, MA, USA). The peptide mixtures were separated at $50{ }^{\circ} \mathrm{C}$ with a constant flow of $400 \mathrm{~nL} / \mathrm{min}$ on a homemade column $(75 \mu \mathrm{m}-$ inner diameter, $250 \mathrm{~mm}$-length) packed with C18 resins $(1.9 \mu \mathrm{m}, 120 \AA$, Dr. Maisch, Ammerbuch, Germany), and eluted with the following binary gradient of mobile phases $\mathrm{A}\left(0.1 \% \mathrm{FA}\right.$ in $\left.\mathrm{H}_{2} \mathrm{O}\right)$ and $\mathrm{B}(0.1 \% \mathrm{FA}$ in $\mathrm{ACN}): 2 \%$ to $17 \% \mathrm{~B}$ for $45.0 \mathrm{~min}, 17 \%$ to $25 \%$ for $22.5 \mathrm{~min}, 25 \%$ to $37 \%$ for $7.5 \mathrm{~min}, 37 \%$ to $80 \%$ for $5.0 \mathrm{~min}$, and then maintained for $10 \mathrm{~min}$ to rinse the analytical column. The timsTOF Pro was operated in PASEF mode using Compass Hystar 5.0.37.1. Settings for MS and MS/MS scans were as follows: mass range 100 to $1700 \mathrm{~m} / z, 1 / \mathrm{K}_{0}$ start $0.6 \mathrm{~V} \cdot \mathrm{s} / \mathrm{cm}^{2}$ end $1.6 \mathrm{~V} \cdot \mathrm{s} / \mathrm{cm}^{2}$, capillary voltage $1400 \mathrm{~V}$, dry gas $3 \mathrm{~L} / \mathrm{min}$, dry temp $180{ }^{\circ} \mathrm{C}$; PASEF mode: $10 \mathrm{MS} / \mathrm{MS}$ scans (total cycle time $1.16 \mathrm{~s}$ ), charge range $0-5$, active exclusion for $0.4 \mathrm{~min}$, scheduling target intensity 20,000, intensity threshold 2500, and CID collision energy 20-59 eV, depending on precursor mass and charge.

\subsection{Data Analysis}

The obtained raw data were submitted to PEAKS Studio 10.5 (Bioinformatics Solutions, Waterloo, ON, Canada) to search against the SwissProt database of Homo sapiens (human, UP00000564, downloaded 22/11/2019, 20379 entries) from Uniprot (www.uniprot. org / (accessed on 20 January 2021)) with a false discovery rate (FDR) of 0.01 for protein identification and label free quantification (LFQ). The search parameters for identification were: (a) trypsin as specific enzyme, two missed cleavage allowed; (b) fixed modification: carbamidomethylation of cysteine and variable modification: oxidation of methionine and acetylation of protein N-term, allowing for three variable PTM per peptide; (c) precursor mass error tolerance of 20.0 ppm; (d) fragment mass error tolerance of $0.05 \mathrm{Da}$. When protein identification was completed, LFQ was carried out using the analyzed PEAKS file. LFQ analysis was performed by analysis of variance (ANOVA) method, and significance thresholds were set to two unique peptides, a data filter in at least three samples per group, a significance of 20 ( $p$-value $=0.01)$, and a 2.0-fold change. Normalization of data was conducted using total ion chromatography (TIC). The resulting data were exported to Microsoft Excel, and a Venn diagram was generated by using an online tool, Venny v2.1 (https:/ / bioinfogp.cnb.csic.es/tools/venny/ (accessed on 20 January 2021)). Heatmap and principal component analysis (PCA) were performed using the Perseus v1.5.8.5.

\section{Results}

\subsection{Silica Nanoparticle Characterization}

For quantitative proteomics of $\mathrm{SiO}_{2} \mathrm{NP}$-induced cytotoxicity, $20 \mathrm{~nm} \mathrm{SiO} 2 \mathrm{NPs}$ were used. The size and morphology characterizations were conducted by using DLS and TEM, respectively. TEM showed that the $\mathrm{SiO}_{2}$ NPs have a spherical morphology with a small size distribution (Figure 1A). In the pristine state, the 20-nm $\mathrm{SiO}_{2} \mathrm{NPs}$ had a diameter of $19.6 \mathrm{~nm}( \pm 0.5)$ when measured by TEM. Hydrodynamic size and zeta potential of the used 
$\mathrm{SiO}_{2} \mathrm{NPs}$ were $21.0 \mathrm{~nm}( \pm 0.1)$ and $-34.3 \mathrm{mV}( \pm 3.5)$, respectively (Table 1). The FT-IR spectrum of $20 \mathrm{~nm} \mathrm{SiO}$ NPs is shown in Figure 1B. In the spectral region, the band at $1080 \mathrm{~cm}^{-1}$ and $804 \mathrm{~cm}^{-1}$ are due to the asymmetric and symmetric stretching vibration of $\mathrm{Si}-\mathrm{O}-\mathrm{Si}$. The band at $973 \mathrm{~cm}^{-1}$ confirms the existence of $\mathrm{Si}-\mathrm{OH}$ stretching vibration [37]. The wide absorption band around $3600-3200 \mathrm{~cm}^{-1}$ is attributable to the stretching of the $\mathrm{OH}$ groups from the physically absorbed water [38]. It has been shown that the $20 \mathrm{~nm} \mathrm{SiO}_{2}$ NP surfaces used in this study are very clean without any organic material.

A

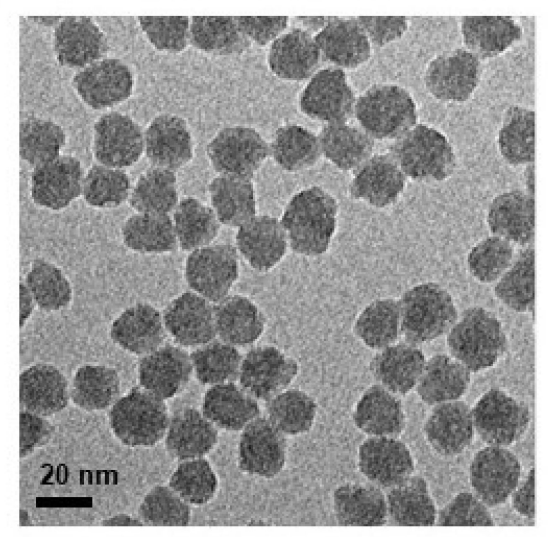

B

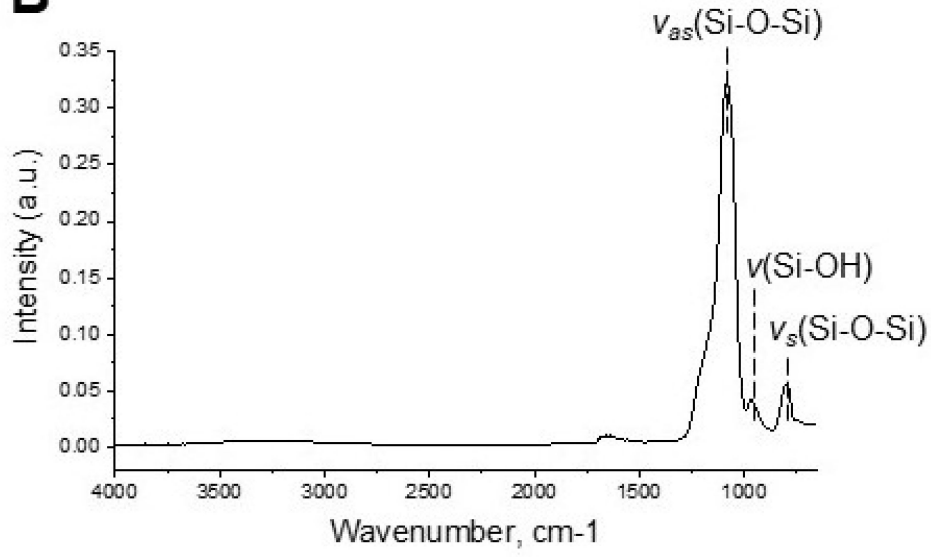

Figure 1. (A) Transmission electron microscopic image and (B) FT-IR spectrum of $20 \mathrm{~nm} \mathrm{SiO} 2$ NPs before culturing with HepG2 cells.

Table 1. Characterization of $\mathrm{SiO}_{2} \mathrm{NPs}(\mathrm{Mean} \pm \mathrm{SD}, n=3$ ).

\begin{tabular}{|c|c|}
\hline Characterization Techniques & $20 \mathrm{~nm} \mathrm{SiO}{ }_{2} \mathrm{NPs}$ \\
\hline TEM (nm) & $19.6 \pm 0.5$ \\
\hline DLS (nm) & $21.0 \pm 0.1$ \\
\hline Polydispersity Index & $0.139 \pm 0.011$ \\
\hline Zeta potential $(\mathrm{mV})$ & $-34.2 \pm 3.5$ \\
\hline
\end{tabular}

\subsection{Cell Viability and LDH Leakage Assays}

To evaluate the toxic effect of $\mathrm{SiO}_{2} \mathrm{NPs}$ on HepG2 cells, bright-field microscopy and the LDH leakage assay were conducted. In the upper images of Figure 2A, no significant change was observed in the control groups from 0 to $16 \mathrm{~h}$. Following $4 \mathrm{~h}$ of exposure to $\mathrm{SiO}_{2} \mathrm{NPs}$ (4 $\mathrm{h} \mathrm{SiO}_{2} \mathrm{NP}$ group), the cellular morphology of HepG2 cells did not change (Figure 2A), while the $\mathrm{LDH}$ level increased for $\mathrm{SiO}_{2} \mathrm{NP}$-treated groups compared with the levels in the $0 \mathrm{~h}$ control group (Figure 2B). The morphological changes were observed in the microscopic data with increasing time after $10 \mathrm{~h}$ exposed to $\mathrm{SiO}_{2} \mathrm{NPs}\left(10 \mathrm{~h} \mathrm{SiO} \mathrm{SP}_{2} \mathrm{NP}\right.$ group); these results corresponded to the increased membrane damage measured by $\mathrm{LDH}$ leakage assay. $\mathrm{LDH}$ levels $16 \mathrm{~h}\left(16 \mathrm{~h} \mathrm{SiO}{ }_{2} \mathrm{NP}\right.$ group $)$ after exposure to $\mathrm{SiO}_{2} \mathrm{NPs}$ increased by $50 \%$ compared to the $0 \mathrm{~h}$ control group. 


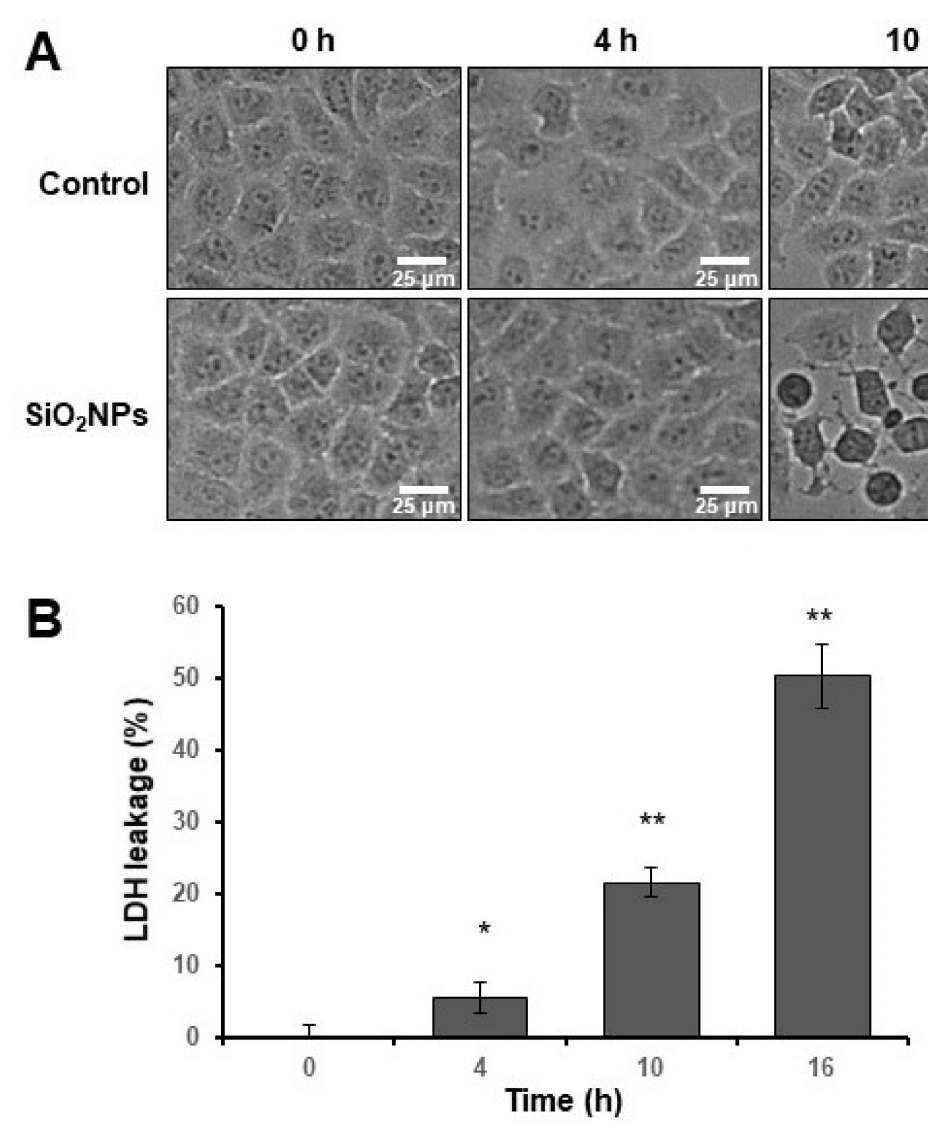

Figure 2. Cell viability assay. (A) The morphologies of HepG2 cells using bright-field microscopy. The upper images are HepG2 cells without $\mathrm{SiO}_{2} \mathrm{NPs}$, and the lower images are $\mathrm{SiO}_{2} \mathrm{NP}(30 \mu \mathrm{g} / \mathrm{mL})$-treated groups exposed for 0, 4, 10, and 16 h. (B) Lactate dehydrogenase (LDH) leakage assay of $\mathrm{SiO}_{2} \mathrm{NP}$-treated groups with increasing exposure time. Data shown are mean \pm standard deviation of three independent experiments. Asterisks indicate effects in comparison to the $0 \mathrm{~h}$ control group $\left({ }^{*} p<0.05,{ }^{* *} p<0.005\right)$.

\subsection{Proteomic Analysis}

To investigate the cellular response to $\mathrm{SiO}_{2} \mathrm{NP}$ exposure through changes in protein levels, we performed $\mathrm{LFQ}$ of $\mathrm{SiO}_{2}$ NP-treated HepG2 cells according to each elapsed time $(4,10$, and $16 \mathrm{~h})$ in comparison with that of each control group. Comparing the results of the 4, 10, and $16 \mathrm{~h} \mathrm{SiO}_{2} \mathrm{NP}$ groups with each control group, a total of 2129, 2504, and 2544 proteins were identified, respectively (Figure 3A). In the three groups, 1937 common proteins were observed. Non-overlapping proteins were also observed in groups of 61, 142, and 189 in 4, 10, and $16 \mathrm{~h}$ groups, respectively. Sixty-one proteins exclusive to the $4 \mathrm{~h}$ group are associated with mitochondria, while 142 and 189 proteins of the 10 and $16 \mathrm{~h}$ groups, respectively, are related to cytosol, cytoplasm, and organelles (Table S1). These results suggest that the biological responses of $\mathrm{SiO}_{2} \mathrm{NPs}$ in HepG2 cells begin in the mitochondria and subsequently occur in the cytoplasm, then the cytosol, followed by the organelles. 
A

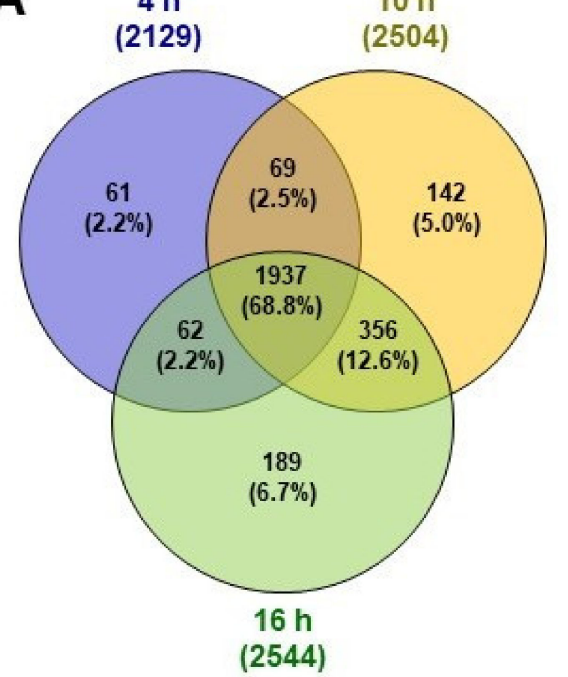

B

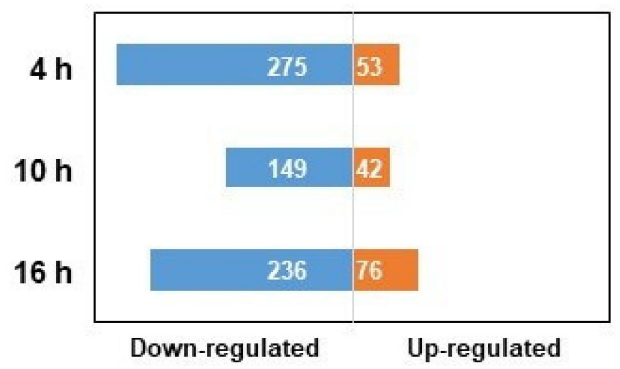

Figure 3. Label-free quantification (LFQ)-based proteomic analysis of HepG2 cells in comparison with controls and $\mathrm{SiO}_{2}$ $\mathrm{NP}$ groups at each time point $\left(4,10\right.$, and $16 \mathrm{~h}$ ). (A) Venn diagram of the quantified proteins after the treatment of $\mathrm{SiO}_{2} \mathrm{NPs}$ for 4, 10, and $16 \mathrm{~h}$. (B) Upregulated and downregulated proteins in HepG2 cells exposed to $\mathrm{SiO}_{2} \mathrm{NPs}$ after 4, 10, and $16 \mathrm{~h}$ compared to their control groups.

We confirmed the trend in cellular response over time through the Venn diagram analysis (Figure 3A). To assess the changes according to time in more detail, proteins which were upregulated and downregulated were extracted from each $\mathrm{SiO}_{2} \mathrm{NP}$ group compared to each control group (Figure $3 \mathrm{~B}$ ). According to the $\mathrm{SiO}_{2} \mathrm{NP}$-treated group and the control group for the $4 \mathrm{~h}$ comparison result, 275 downregulated and 53 upregulated proteins were observed. In HepG2 cells, 149 downregulated and 42 upregulated proteins were detected as the $\mathrm{SiO}_{2}$ NPs treatment time elapsed for $10 \mathrm{~h}$, but the number of the differentially expressed proteins over exposure of $\mathrm{SiO}_{2} \mathrm{NPs}$ after $16 \mathrm{~h}$ were increased (236 downregulated and 76 upregulated proteins). We attempted to analyze the time course of cytotoxicity by constructing a protein-protein interaction network using the STRING algorithm for differently expressed proteins between time groups. Following $4 \mathrm{~h}$ of exposure to $\mathrm{SiO}_{2} \mathrm{NPs}$, downregulated proteins were related to the ribosome, mRNA splicing, RNA transport, and the cell cycle (Figure 4A). Some of these proteins which were involved in ribosomes, mRNA splicing, and cell cycle were shown to be continuously downregulated even in the $10 \mathrm{~h}$ (Figure $4 \mathrm{C}$ ) and $16 \mathrm{~h} \mathrm{SiO}_{2} \mathrm{NP}$ groups (Figure 4E). The 53 proteins upregulated in the $4 \mathrm{~h}$ group were associated with immune system and DNA damage/telomeres stress-induced aging (Figure 4B), and the same interaction was found at $10 \mathrm{~h}$ (Figure 4D). In the $16 \mathrm{~h} \mathrm{SiO}_{2} \mathrm{NP}$ group, upregulated proteins involved in the immune system and DNA damage/telomere stress-induced senescence were found to be increased, and proteins related to oxidative phosphorylation were detected (Figure 4F). In previous studies, it has been reported that oxidative phosphorylation proteins were upregulated under the influence of $\mathrm{ROS}$ generated from $\mathrm{SiO}_{2} \mathrm{NPs}$ [39-41]. To determine whether these proteins were indeed affected by ROS production in our system, $\mathrm{H}_{2}$-DCF-DA staining was performed to measure ROS levels in HepG2 cells in accordance with the elapsed time after exposure to $\mathrm{SiO}_{2} \mathrm{NPs}$. There was no significant change even after exposure to $\mathrm{SiO}_{2} \mathrm{NPs}$ for $4 \mathrm{~h}$ compared to the $0 \mathrm{~h}$ control group; however, after $10 \mathrm{~h}$, it was confirmed that the ROS level significantly increased with elapsed time (Figure S1). Based on these results, we demonstrated that ROS produced by $\mathrm{SiO}_{2} \mathrm{NP}$-induced cellular responses in HepG2 cells such as oxidative phosphorylation and immune system. Detailed information for down- and upregulated proteins involved in specific interactions as indicated in Figure 4 is described in Tables S2 and S3, respectively. 
A

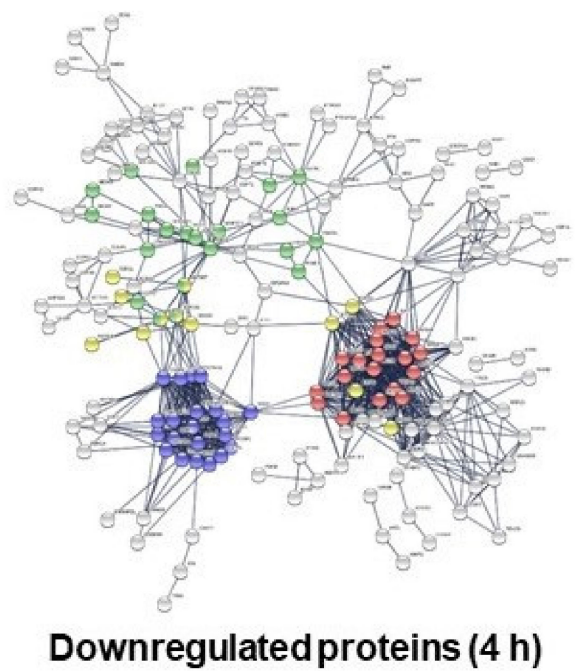

C

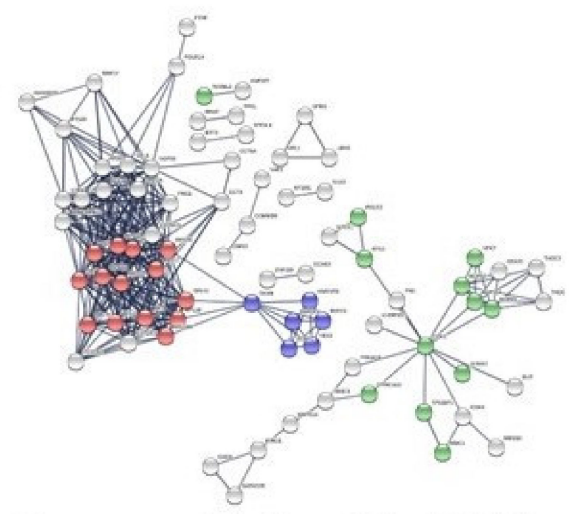

Downregulated proteins $(10 \mathrm{~h})$

E

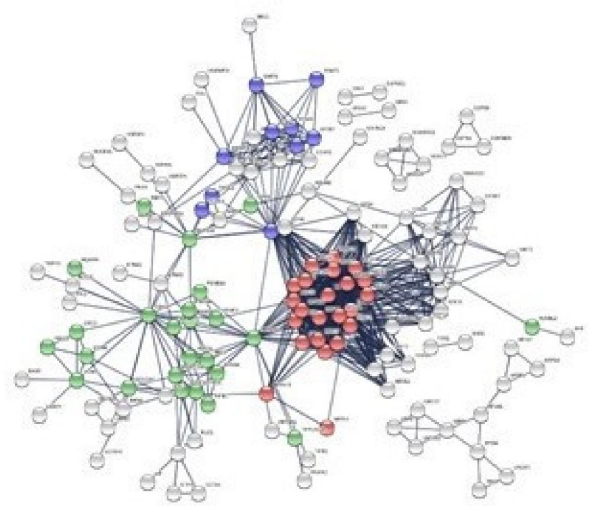

Downregulated proteins (16 h)
B

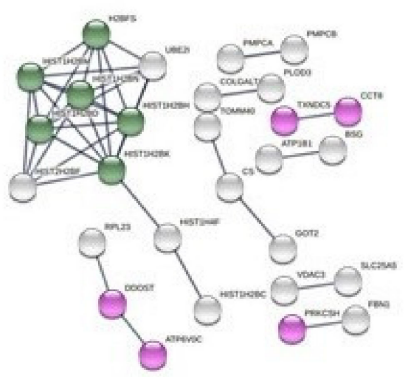

\section{Upregulated proteins (4 h)}

D

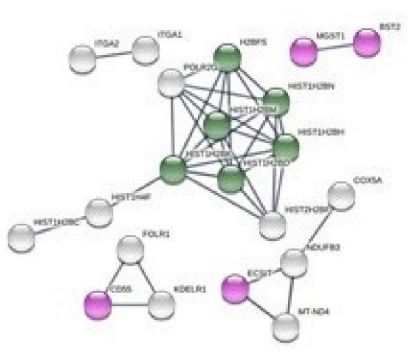

Upregulated proteins $(10 \mathrm{~h})$

$\mathbf{F}$

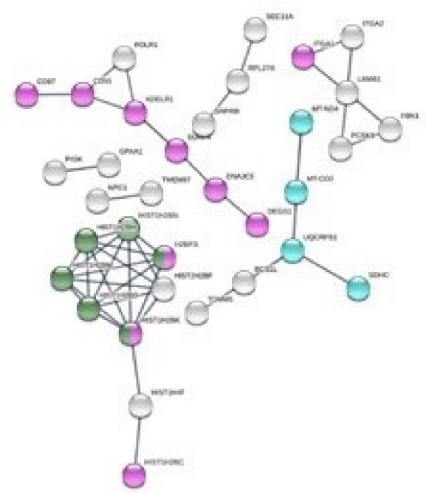

Upregulated proteins (16 h)

\section{(9) Ribosome \\ mRNA splicing \\ RNA transport \\ Cell cycle \\ Immune system \\ DNA damage/Telomere stress induced senescence \\ Oxidative phosphorylation}

Figure 4. Protein-protein interaction networks (PPI) of differentially expressed proteins in $\mathrm{HepG}_{2}$ cells regulated by $\mathrm{SiO}_{2}$ NPs using a STRING algorithm. The color circles represent the cellular interaction with highest confidence (score $\geq 0.9)$ are shown. PPI of downregulated and upregulated proteins for (A,B) 4, (C,D) 10, and (E,F) 16 h groups. 
To investigate changes to proteins involved in specific biological pathways over the time of exposure to $\mathrm{SiO}_{2} \mathrm{NPs}$ in HepG2 cells, four control groups $(0,4,10$, and $16 \mathrm{~h})$ and three experimental groups $\left(4,10\right.$, and $16 \mathrm{~h} \mathrm{SiO}_{2} \mathrm{NP}$ groups) simultaneously underwent LFQ-based proteomic analysis. From the proteomic analysis, the result was confirmed the intracellular effects generated from both serum-free and the $\mathrm{SiO}_{2} \mathrm{NPs}$. Considering that the proteins level did not change significantly in the control group, whereas the proteins were upregulated and downregulated in the $\mathrm{SiO}_{2} \mathrm{NPs}$ group, it can be seen that the significant changes on HepG2 cells resulted from $\mathrm{SiO}_{2} \mathrm{NPs}$ rather than a serum-free environment. A total of 1668 proteins were quantified through the analysis, and 482 proteins were differentially expressed with correlations among the seven groups. As a result of drawing heat maps of 482 proteins with correlations among the seven groups, 363 downregulated (green color) and 119 upregulated proteins (red color) were quantified compared to $0 \mathrm{~h}$ control (Figure 5A). Principal component analysis was performed using the differentially expressed proteins, which revealed that the principal components distinctly differed among the $\mathrm{SiO}_{2} \mathrm{NP}$-treated groups compared to control groups (Figure $5 \mathrm{~B}$ ). With regards to the first component, the largest difference was observed between the controls and $\mathrm{SiO}_{2} \mathrm{NP}$ groups. In addition, it was confirmed that the $\mathrm{SiO}_{2} \mathrm{NPs}$ treated group can be classified by time through principal component 2. Based on these results, it was possible to understand the cellular response over time after exposure to $\mathrm{SiO}_{2} \mathrm{NPs}$ by assessing the changes in protein levels.

A
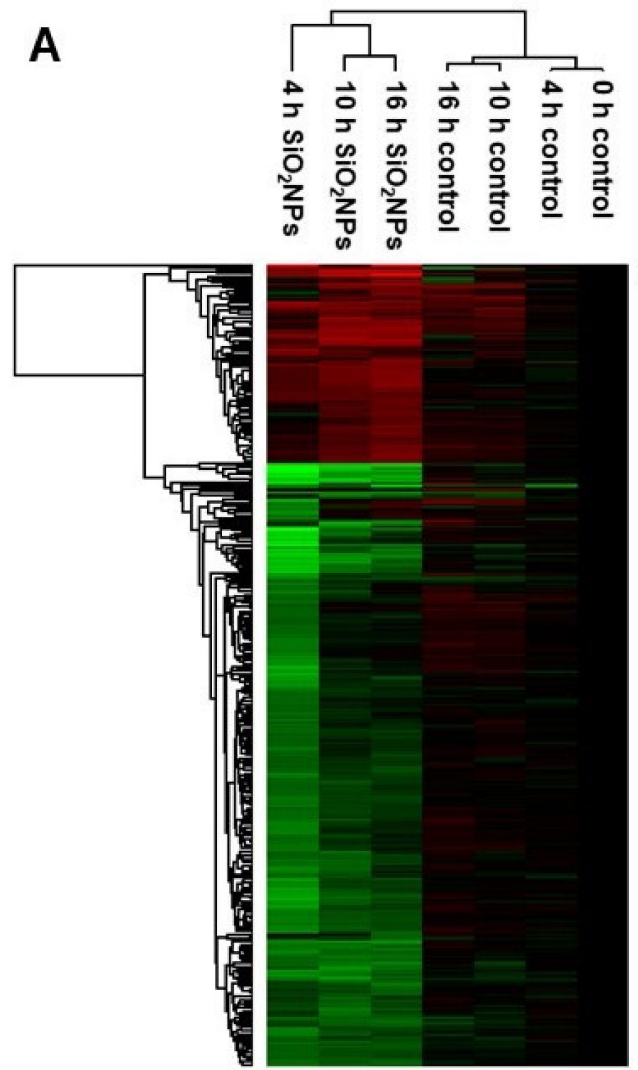

B

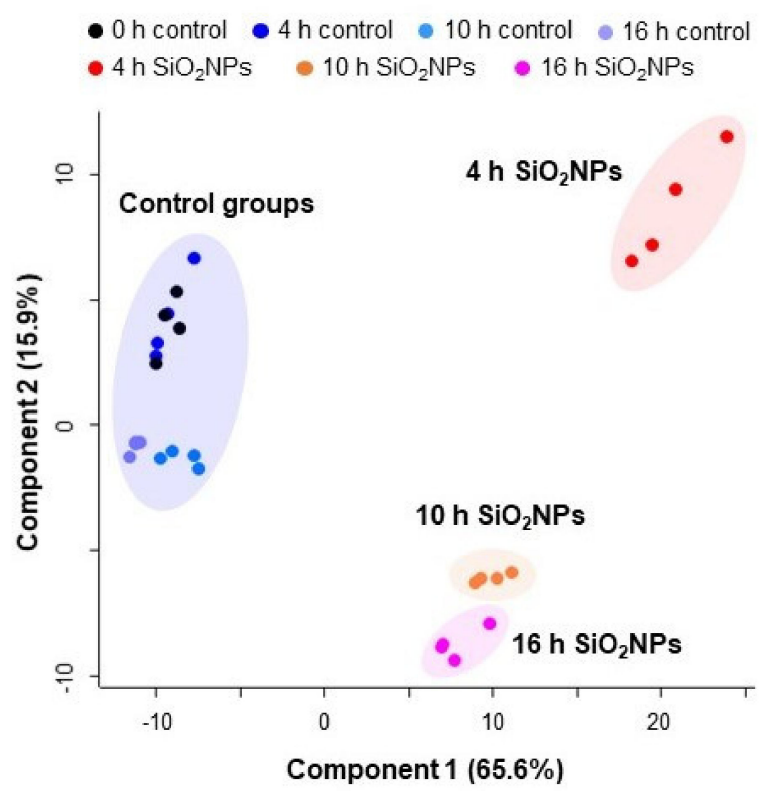

Figure 5. (A) Heatmap (with hierarchical cluster analysis) and (B) principal component analysis of the differentially expressed proteins from $\mathrm{SiO}_{2}$ NPs-treated HepG2 cells in increase of exposure time in comparison to the $0 \mathrm{~h}$ group. The filled circles of the same color represent four duplicates.

To explore the detailed cellular responses to $\mathrm{SiO}_{2} \mathrm{NP}$ exposure, we investigated the specific pathways associated with the differentially expressed proteins among the six groups compared to the 0-h control. As shown in Table 2, mitochondrial-related proteins, such as cell cycle and apoptosis regulator protein 2 (CCAR2), vacuolar protein sorting- 
associated protein 35 (VPS35) and dynamin-1-like protein (DNM1) were downregulated after exposure to $\mathrm{SiO}_{2} \mathrm{NPs}$, whereas these proteins in control groups were unchanged and VPS35 in the $16 \mathrm{~h}$ control was upregulated. These results indicate that $\mathrm{SiO}_{2} \mathrm{NPs}_{\text {introduced }}$ into cells have a direct effect on mitochondria. The exposure of $\mathrm{SiO}_{2} \mathrm{NPs}$ in HepG2 cells affects the regulation of proteins involved in the cell cycle including nucleoprotein TPR (TPR), ubiquitin-conjugating enzyme E2 N (UBE2N), and cyclin-dependent kinase 1 (CDK1) [42]. In addition, proteins associated with DNA replication, such as DNA polymerase delta subunit 3 (DPOD3), ATP-dependent RNA helicase A (DHX9), and RNA-binding protein 14 (RBM14) were more downregulated in the $4 \mathrm{~h}$ group of HepG2 cells with $\mathrm{SiO}_{2}$ NPs. Likewise, the most downregulated pathway in the $4 \mathrm{~h} \mathrm{SiO} \mathrm{NP}_{2}$ group was related to spliceosomes, and the proteins involved were measured for SNW domain-containing protein 1 (SNW1), RNA-binding protein 25 (RBM25), and Probable ATP-dependent RNA helicase DDX46 (DDX46). This result may suggest that protein-protein interactions associated with mRNA splicing in Figure 4 occurs via spliceosomes. Finally, carbon metabolism-related proteins, such as alpha-enolase (ENOA), cytoplasmic aconitate hydratase (ACOC), and ATP-dependent 6-phosphofructokinase muscle type (PFKAM), were also downregulated by $\mathrm{SiO}_{2}$ NPs.

We also investigated the major cellular pathways associated with the proteins observed to have been upregulated, as listed in Table 3. Among the upregulated proteins, endosome-related proteins, including anthrax toxin receptor 1 (ANTR1), thioredoxin domain-containing protein 5 (TXND5), and CD81 antigen (CD81), were significantly upregulated $4 \mathrm{~h}$ after exposure to $\mathrm{SiO}_{2} \mathrm{NPs}$, and continued to be upregulated up to $16 \mathrm{~h}$. Proteins associated with the phagosome, such as HLA class I histocompatibility antigen A alpha chain (HLAA), integrin beta-1 (ITB1), and V-type proton STPase subunit d1 (VA0D1), were upregulated in the $10 \mathrm{~h} \mathrm{SiO} 2 \mathrm{NP}$ group; most of these were upregulated to a greater extent with increasing exposure time to $\mathrm{SiO}_{2}$ NPs. When extrinsic substances are introduced into cells by endosomes and phagosomes, the production of lysosomes is activated to decompose these substances. Thus, it can be seen that some of the proteins associated with the lysosome, such as dolichyl-diphosphooligosaccharide-protein glycosyltransferase 48 kDa subunit (OST48), lysosome-associated membrane glycoprotein 2 (LAMP2), and prenylcysteine oxidase 1 (PCYOX), were upregulated in the $4 \mathrm{~h} \mathrm{SiO}_{2} \mathrm{NP}$ group, and most of the proteins were significantly upregulated in the $10 \mathrm{~h} \mathrm{SiO} \mathrm{NP}_{2}$ group. Since endosomes and phagosomes continue to form until an elapsed time of $16 \mathrm{~h}$, it was observed that proteins related to lysosomes were significantly upregulated even in the $16 \mathrm{~h} \mathrm{SiO}_{2} \mathrm{NP}_{\text {group. Unlike }}$ carbon metabolism, most proteins involved in lipid metabolism, including lysophospholipid acyltransferase 7 (MBOA7), sphingolipid delta(4)-desaturase DES1 (DEGS1), and medium-chain specific acyl-CoA dehydrogenase (ACADM), were significantly upregulated in the 10 and $16 \mathrm{~h} \mathrm{SiO}_{2} \mathrm{NP}$ groups. Some proteins are upregulated in the control without $\mathrm{SiO}_{2} \mathrm{NP}$, but since these proteins are further upregulated in the presence of $\mathrm{SiO}_{2} \mathrm{NP}$, it was confirmed that several intracellular pathways are affected by $\mathrm{SiO}_{2}$ NP. In Figure 6, MS and tandem MS spectra for four representative proteins involved in the biological pathways are shown. The representative downregulated [CDK1 (LESEEEGVSTAIR) and ACOC (QAPQTIHLPSGEILDVFDAAER)] and upregulated proteins [ACADM (IYQIYEGTSQIQR) and LAMP2 (GILTVDELLAIR)] were also found. 
Table 2. List of downregulated proteins from control and $\mathrm{SiO}_{2} \mathrm{NP}$ groups of HepG2 cells by the exposure time associated with the biological pathway.

\begin{tabular}{|c|c|c|c|c|c|c|c|c|}
\hline \multirow{3}{*}{ Protein } & \multirow{3}{*}{ Description } & \multicolumn{6}{|c|}{ Fold Change Compared to $0 \mathrm{~h}$ Control } & \multirow{3}{*}{$p$-Value } \\
\hline & & \multicolumn{3}{|c|}{ Control (h) } & \multicolumn{3}{|c|}{$\mathrm{SiO}_{2} \mathrm{NPs}(\mathrm{h})$} & \\
\hline & & 4 & 10 & 16 & 4 & 10 & 16 & \\
\hline \multicolumn{9}{|c|}{ Mitochondria } \\
\hline CARE & Cell cycle and apoptosis regulator protein 2 & 1.06 & 0.96 & 1.25 & 0.54 & 0.38 & 0.55 & $2.09 \times 10^{-7}$ \\
\hline VPS35 & Vacuolar protein sorting-associated protein 35 & 1.07 & 1.32 & 1.51 & 0.39 & 0.88 & 0.91 & $3.52 \times 10^{-7}$ \\
\hline DNM1L & Dynamin-1-like protein & 1.04 & 1.08 & 1.03 & 0.47 & 0.77 & 0.66 & $2.19 \times 10^{-5}$ \\
\hline \multicolumn{9}{|c|}{ Cell Cycle Checkpoint } \\
\hline TPR & Nucleoprotein TPR & 1.06 & 1.14 & 1.12 & 0.39 & 0.52 & 0.57 & $1.32 \times 10^{-9}$ \\
\hline UBE2N & Ubiquitin-conjugating enzyme E2 N & 0.94 & 1.20 & 1.19 & 0.36 & 0.68 & 0.62 & $6.41 \times 10^{-9}$ \\
\hline PRKDC & DNA-dependent protein kinase catalytic subunit & 1.04 & 1.11 & 1.17 & 0.42 & 0.63 & 0.84 & $1.25 \times 10^{-8}$ \\
\hline MDC1 & Mediator of DNA damage checkpoint protein 1 & 0.93 & 1.00 & 1.11 & 0.39 & 0.50 & 0.54 & $1.48 \times 10^{-8}$ \\
\hline $\mathrm{PCH} 2$ & Pachytene checkpoint protein 2 homolog & 1.11 & 1.35 & 1.20 & 0.18 & 0.56 & 0.78 & $6.76 \times 10^{-8}$ \\
\hline PIP30 & PSME3-interacting protein & 1.00 & 0.88 & 0.82 & 0.47 & 0.44 & 0.44 & $6.84 \times 10^{-8}$ \\
\hline CDK1 & Cyclin-dependent kinase 1 & 1.01 & 0.94 & 1.13 & 0.38 & 0.45 & 0.45 & $8.97 \times 10^{-8}$ \\
\hline NSUN2 & RNA cytosine C(5)-methyltransferase NSUN2 & 1.02 & 0.85 & 0.94 & 0.45 & 0.38 & 0.41 & $1.14 \times 10^{-7}$ \\
\hline MARE1 & Microtubule-associated protein RP/EB family member 1 & 1.00 & 1.12 & 1.26 & 0.31 & 0.75 & 0.68 & $6.67 \times 10^{-7}$ \\
\hline NU107 & Nuclear pore complex protein Nup107 & 0.97 & 0.97 & 1.18 & 0.44 & 0.67 & 0.66 & $1.08 \times 10^{-6}$ \\
\hline MRE11 & Double-strand break repair protein MRE11 & 1.02 & 1.20 & 1.47 & 0.41 & 0.52 & 0.72 & $1.11 \times 10^{-6}$ \\
\hline PSD13 & $26 \mathrm{~S}$ proteasome non-ATPase regulatory subunit 13 & 1.04 & 0.82 & 0.86 & 0.47 & 0.58 & 0.50 & $1.82 \times 10^{-6}$ \\
\hline PTN11 & Tyrosine-protein phosphatase non-receptor type 11 & 1.10 & 1.24 & 1.16 & 0.48 & 0.76 & 0.60 & $4.69 \times 10^{-6}$ \\
\hline PCNA & Proliferating cell nuclear antigen & 1.07 & 1.01 & 1.35 & 0.37 & 0.61 & 0.74 & $1.08 \times 10^{-5}$ \\
\hline TP53B & TP53-binding protein 1 & 0.67 & 1.07 & 0.94 & 0.18 & 0.32 & 0.44 & $4.89 \times 10^{-5}$ \\
\hline ZW10 & Centromere/kinetochore protein zw10 homolog & 0.90 & 1.13 & 0.84 & 0.25 & 0.78 & 0.96 & $8.63 \times 10^{-3}$ \\
\hline \multicolumn{9}{|c|}{ DNA Replication } \\
\hline THOC4 & THO complex subunit 4 & 0.99 & 0.99 & 1.03 & 0.39 & 0.55 & 0.56 & $1.08 \times 10^{-12}$ \\
\hline NUCKS & $\begin{array}{l}\text { Nuclear ubiquitous casein and cyclin-dependent kinase } \\
\text { substrate } 1\end{array}$ & 0.98 & 1.03 & 1.12 & 0.23 & 0.36 & 0.48 & $2.71 \times 10^{-11}$ \\
\hline
\end{tabular}


Table 2. Cont.

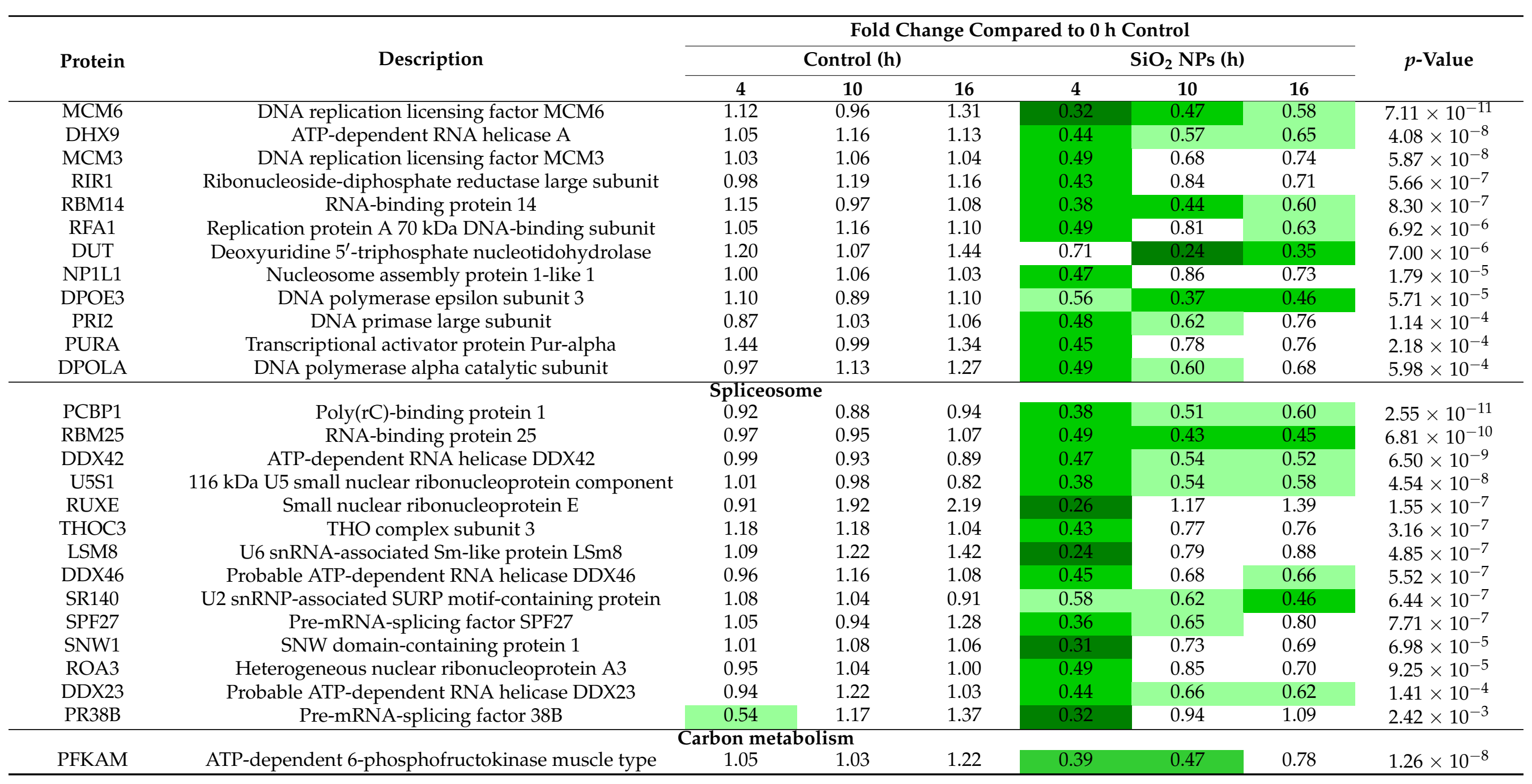


Table 2. Cont.

\begin{tabular}{|c|c|c|c|c|c|c|c|c|}
\hline \multirow{3}{*}{ Protein } & \multirow{3}{*}{ Description } & \multicolumn{6}{|c|}{ Fold Change Compared to $0 \mathrm{~h}$ Control } & \multirow{3}{*}{$p$-Value } \\
\hline & & \multicolumn{3}{|c|}{ Control (h) } & \multicolumn{3}{|c|}{$\mathrm{SiO}_{2}$ NPs (h) } & \\
\hline & & 4 & 10 & 16 & 4 & 10 & 16 & \\
\hline ENOA & Alpha-enolase & 1.02 & 1.13 & 1.08 & 0.25 & 0.49 & 0.58 & $1.93 \times 10^{-8}$ \\
\hline ACOC & Cytoplasmic aconitate hydratase & 1.16 & 1.12 & 1.37 & 0.38 & 0.63 & 0.84 & $1.26 \times 10^{-7}$ \\
\hline PFKAP & ATP-dependent 6-phosphofructokinase platelet type & 1.01 & 1.06 & 1.18 & 0.34 & 0.46 & 0.70 & $2.83 \times 10^{-7}$ \\
\hline IDH3A & Isocitrate dehydrogenase [NAD] subunit alpha & 1.00 & 0.78 & 1.02 & 0.22 & 0.44 & 0.57 & $2.99 \times 10^{-7}$ \\
\hline PGP & Glycerol-3-phosphate phosphatase & 0.97 & 1.11 & 1.12 & 0.19 & 0.40 & 0.71 & $1.86 \times 10^{-6}$ \\
\hline ODPB & $\begin{array}{l}\text { Pyruvate dehydrogenase E1 component subunit beta } \\
\text { mitochondrial }\end{array}$ & 1.14 & 0.71 & 1.12 & 0.27 & 0.56 & 0.47 & $7.91 \times 10^{-6}$ \\
\hline IDH3B & Isocitrate dehydrogenase [NAD] subunit beta & 1.09 & 1.03 & 1.14 & 0.37 & 0.79 & 0.77 & $8.67 \times 10^{-6}$ \\
\hline ALDOC & Fructose-bisphosphate aldolase C & 1.03 & 1.28 & 1.25 & 0.49 & 1.07 & 1.09 & $2.17 \times 10^{-5}$ \\
\hline MAOX & NADP-dependent malic enzyme & 0.82 & 0.86 & 0.93 & 0.46 & 0.53 & 0.73 & $2.48 \times 10^{-4}$ \\
\hline
\end{tabular}

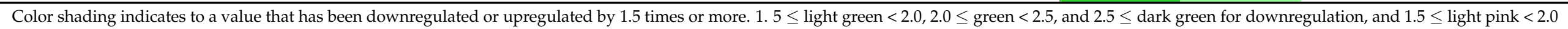

for upregulation.

Table 3. List of upregulated proteins from control and $\mathrm{SiO}_{2} \mathrm{NP}$ groups of HepG2 cells by the exposure time associated with the biological pathway.

\begin{tabular}{|c|c|c|c|c|c|c|c|c|}
\hline \multirow{3}{*}{ Protein } & \multirow{3}{*}{ Description } & \multicolumn{6}{|c|}{ Fold Change Compared to $0 \mathrm{~h}$ Control } & \multirow{3}{*}{$p$-Value } \\
\hline & & \multicolumn{3}{|c|}{ Control (h) } & \multicolumn{3}{|c|}{$\mathrm{SiO}_{2}$ NPs (h) } & \\
\hline & & 4 & 10 & 16 & 4 & 10 & 16 & \\
\hline \multicolumn{9}{|c|}{ Endosome } \\
\hline CD81 & CD81 antigen & 1.04 & 1.31 & 1.24 & 2.92 & 4.84 & 6.26 & $1.27 \times 10^{-9}$ \\
\hline EGFR & Epidermal growth factor receptor & 0.97 & 1.28 & 1.11 & 1.18 & 1.91 & 2.13 & $1.41 \times 10^{-9}$ \\
\hline ANTR1 & Anthrax toxin receptor 1 & 1.02 & 1.12 & 1.00 & 1.72 & 2.48 & 3.09 & $3.94 \times 10^{-8}$ \\
\hline FOLR1 & Folate receptor alpha & 0.59 & 1.02 & 1.27 & 1.08 & 2.20 & 2.78 & $5.87 \times 10^{-8}$ \\
\hline FLOT2 & Flotillin-2 & 1.62 & 1.26 & 0.57 & 0.89 & 1.56 & 2.93 & $8.51 \times 10^{-7}$ \\
\hline A4 & Amyloid-beta precursor protein & 0.87 & 0.87 & 0.99 & 1.37 & 2.07 & 1.83 & $1.45 \times 10^{-6}$ \\
\hline TXND5 & Thioredoxin domain-containing protein 5 & 0.94 & 1.70 & 1.49 & 1.82 & 2.23 & 2.01 & $1.62 \times 10^{-6}$ \\
\hline LG3BP & Galectin-3-binding protein & 1.07 & 1.31 & 1.44 & 1.27 & 2.03 & 2.49 & $2.01 \times 10^{-6}$ \\
\hline B2MG & Beta-2-microglobulin & 1.06 & 1.24 & 1.38 & 1.62 & 1.98 & 2.23 & $2.81 \times 10^{-6}$ \\
\hline
\end{tabular}


Table 3. Cont.

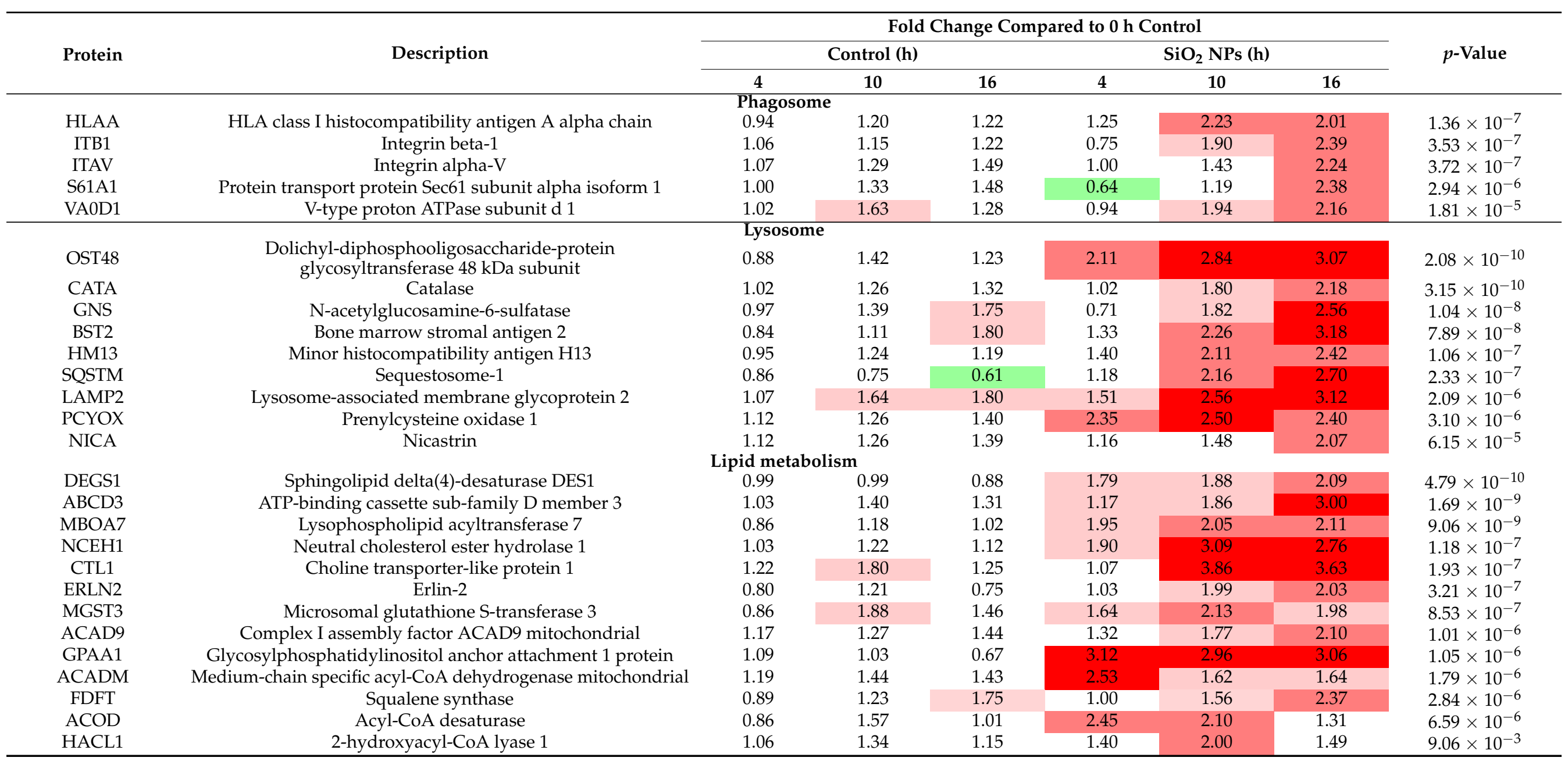

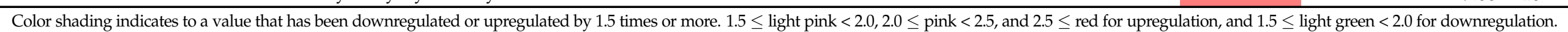


CDK1 : LESEEEGVPSTAIR $(z=2, m / z=758.88)$
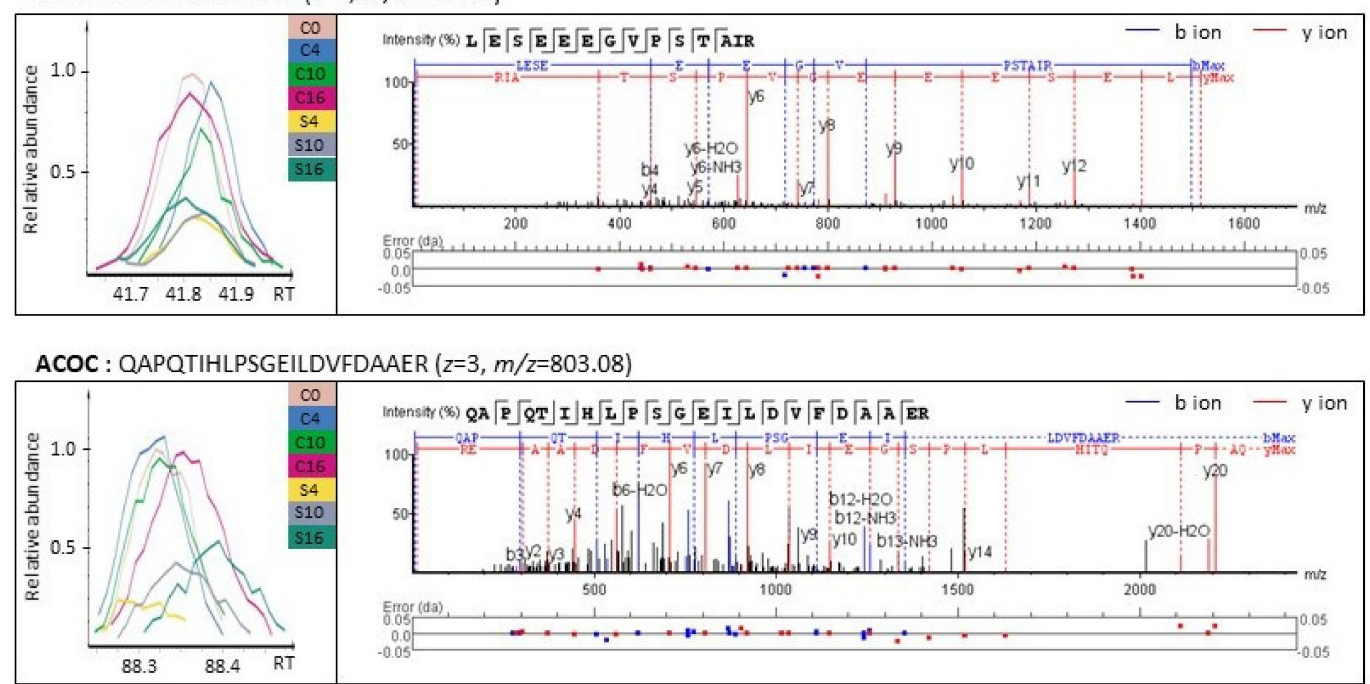

ACADM : IYQIYEGTSQIQR $(z=2, m / z=799.91)$

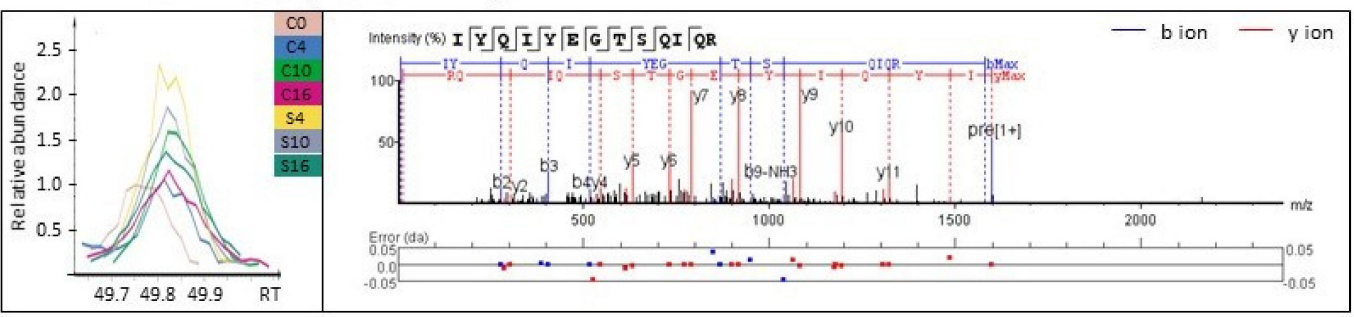

LAMP2 : GILTVDELLAIR $(z=2, m / z=656.89)$

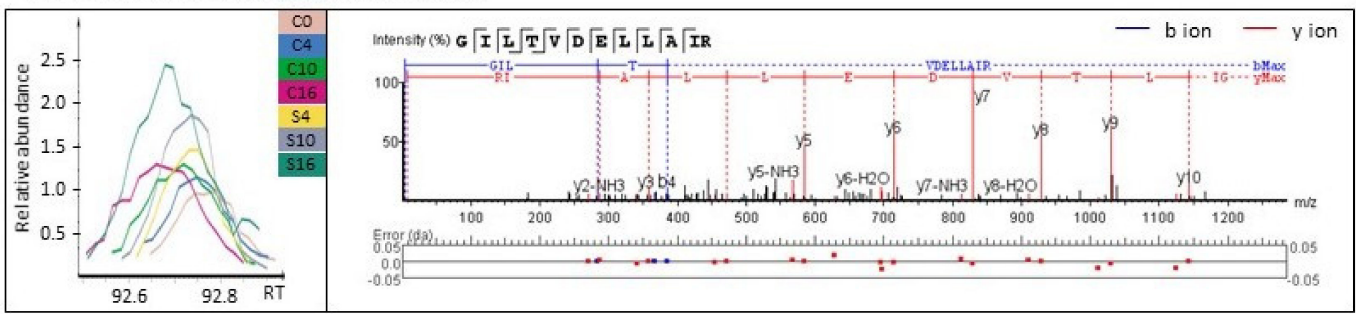

Figure 6. Representative MS and tandem MS spectra of downregulated (CDK1 and ACOC) and upregulated proteins (ACADM and LAMP2) in $\mathrm{SiO}_{2}$ NP-treated groups, which are involved in cell cycle checkpoint, carbon metabolism, lipid metabolism, and lysosome. Data were obtained using the software PEAKS Studio 10.5. (Abbreviations: CDK1, cyclindependent kinase 1; ACOC, cytoplasmic aconitate hydratase; ACADM, medium-chain specific acyl-CoA dehydrogenase mitochondrial; LAMP2, lysosome-associated membrane glycoprotein 2).

\section{Discussion}

As $\mathrm{SiO}_{2} \mathrm{NPs}$ are widely used in the field of nanomedicine, food additives, and consumer products, detailed studies into their safety and biological toxicity are required. $\mathrm{SiO}_{2}$ NPs are easily introduced into cells at a size of $50 \mathrm{~nm}$ or lower and are known to cause toxicity when used at a concentration of $25 \mu \mathrm{g} / \mathrm{mL}$ or higher after $24 \mathrm{~h}$ in vitro [11,12,43]. Recent studies have demonstrated various pathways for $\mathrm{SiO}_{2} \mathrm{NP}$-induced apoptosis, such as DNA damage [44-46], lysosome-induced cell death [47], and mitochondrial dysfunction [48,49]. However, most of these studies are the results of cellular responses following at least $24 \mathrm{~h}$ of exposure to these nanoparticles. It is known that uptake of the nanoparticles begins as rapidly as $15 \mathrm{~min}$ after cellular exposure, and this uptake is associated with several intracellular reactions leading to cytotoxicity [43]. In this study, we investigated the biological reaction to these nanoparticles at multiple time points $(0,4,10$, and $16 \mathrm{~h})$ after 
cellular entry of $\mathrm{SiO}_{2} \mathrm{NPs}$ compared to cells not treated with $\mathrm{SiO}_{2} \mathrm{NPs}$. Furthermore, we investigated the molecular mechanisms underlying their cytotoxicity through LFQ-based proteomic analysis. Interestingly, analysis of differentially expressed proteins in response to $\mathrm{SiO}_{2} \mathrm{NP}$ exposure led to a clear understanding of a temporal pattern in cellular response to $20 \mathrm{~nm} \mathrm{SiO} 2$ NPs and their cytotoxic potential. The protein profiling approach is a useful tool to determine how cells induce cytotoxicity when exposed to nanoparticles and how these changes ultimately result in cell death, as overall changes in protein levels be detected even in the absence of significant extracellular changes.

Exogenous substances such as nanoparticles enter cells through endocytic and phagocytic pathway [50,51]. In our study, the $\mathrm{SiO}_{2} \mathrm{NPs}$ were firstly introduced into HepG2 cells through endocytic pathway, considering that endocytosis-related proteins were upregulated in the $4 \mathrm{~h} \mathrm{SiO} 2 \mathrm{NP}$ groups. In particular, the increase in Flotullin-2 (FLOT2) is expected to cause flotillin-dependent endocytosis [52]. Phagosome-related proteins were upregulated at $10 \mathrm{~h}$, which is speculated that introduced into cells after an aggregation due to exposure of the nanoparticles to the media. The endosome and phagosome formed in the cell are combine with the lysosomes to form endolysosomes and phagolysosomes, respectively. These complexes containing the ingested $\mathrm{SiO}_{2} \mathrm{NPs}$ fuse with lysosomes are then decomposed by enzyme-catalyzed hydrolysis [50]. Some of the lysosome-related proteins were upregulated in the $4 \mathrm{~h}$ group, and many proteins related to lysosomes were continuously upregulated from 10 to $16 \mathrm{~h}$ following exposure to $\mathrm{SiO}_{2} \mathrm{NPs}$. These results demonstrated that when HepG2 cells are exposed to $\mathrm{SiO}_{2} \mathrm{NPs}$, endocytosis occurs within $4 \mathrm{~h}$, phagocytosis occurs at $10 \mathrm{~h}$, and lysosomal proteins involved in the decomposition of foreign substances begin to activate from $4 \mathrm{~h}$ and continue to be upregulated until 16 h. HepG2 cells exposed to silica nanoparticles were observed to downregulate proteins related to ribosomes and mRNA splicing in the $4 \mathrm{~h}$ group. Changes in these proteins are known to induce DNA damage when exogenous damaging substances are introduced into cells $[53,54]$. In many studies, DNA damage has been reported to be caused by ROS after exposure to nanoparticles $[11,25,55]$. However, in this study, ROS was found to increase $10 \mathrm{~h}$ after exposure to $\mathrm{SiO}_{2} \mathrm{NPs}$. These results suggest that the downregulation of proteins associated with mRNA splicing and ribosomes within $4 \mathrm{~h}$ in HepG2 cells could be attributed to DNA damage caused by $\mathrm{SiO}_{2} \mathrm{NPs}$ directly, not ROS. In addition, downregulated proteins related to mRNA splicing and ribosomes subsequently affected DNA replication and cell cycle arrest [53]. In particular, important factors in the regulation of the G2/M phase of the cell cycle is CDK1. Downregulation of G2/M phase-related proteins induces cell cycle arrest, eventually leading to cell death. These results are consistent with previous studies involving cell cycle arrest when cells were exposed to $\mathrm{SiO}_{2} \mathrm{NPs}[11,42,56,57]$.

Previous studies have reported mitochondrial damage caused by nanoparticles or ROS as a major cause of $\mathrm{SiO}_{2} \mathrm{NPs}$ cytotoxicity $[40,41,44,48]$. In our results, we confirmed that mitochondria-related proteins were significantly downregulated in the $4 \mathrm{~h} \mathrm{SiO}_{2} \mathrm{NP}$ group. These results suggest that the factor inducing mitochondrial damage in HepG2 cells is $\mathrm{SiO}_{2} \mathrm{NPs}$ itself. The nanoparticles introduced into the cells activated the immune system from the beginning of the introduction and caused DNA damage, in which the tendency remained the same even in the $10 \mathrm{~h}$ groups. After $16 \mathrm{~h}$ of exposure to $\mathrm{SiO}_{2} \mathrm{NPs}$, oxygen molecules produced by ROS activate oxidative phosphorylation by upregulating cytochrome b-c1 complex subunit Rieske (UQCRFS1), cytochrome c oxidase subunit 2 (MT-CO2), NADH-ubiquinone oxidoreductase chain 4 (MT-ND4), and succinate dehydrogenase cytochrome b560 subunit (SDHC). Furthermore, the proteins involved in lipid metabolism such as DEGS1, MBOA7, and ACADM were also upregulated in the 10 and $16 \mathrm{~h}$ groups. Duan et al. confirmed that the proteins involved in hepatic lipid metabolism were upregulated when exposed to $\mathrm{SiO}_{2} \mathrm{NPs}$; these results are consistent with our results [21]. In contrast, the carbon metabolism-related proteins, which regulate energy production, were downregulated in the $4 \mathrm{~h}$ group. Lee et al. demonstrated that exposure to $\mathrm{SiO}_{2}$ NPs in human embryonic kidney 293 (HEK293) cells resulted in disorders of glucose metabolism as well as glucose uptake [58,59]. Gradually, as the exposure time of $\mathrm{SiO}_{2}$ 
NPs increases, cellular responses such as lipid metabolism and oxidative phosphorylation increase, and lead to the activation of the immune system. The analysis of intracellular changes in HepG2 that occurred $16 \mathrm{~h}$ after exposure to $\mathrm{SiO}_{2} \mathrm{NPs}$ allowed a closer look at the mechanisms of early cytotoxicity. When $\mathrm{SiO}_{2} \mathrm{NPs}$ are exposed to cells for longer periods, the cells eventually die through a cytotoxic pathway, such as autophagy $[60,61]$, apoptosis $[9,62,63]$, lysosome-induced cell death [47,50], and necrosis [10,30,64] (Figure 7). Although this study focused on global changes in the early stages of nanoparticle exposure, we expect that proteomic analysis following a future separate organelle-based study will enable a deeper understanding of the molecular processes underlying their cytotoxicity and eventuating in $\mathrm{SiO}_{2} \mathrm{NP}$-induced cell death. Additionally, the complementary research with a biological assay will provide a more detailed mechanism and biological pathway at a specific time point.

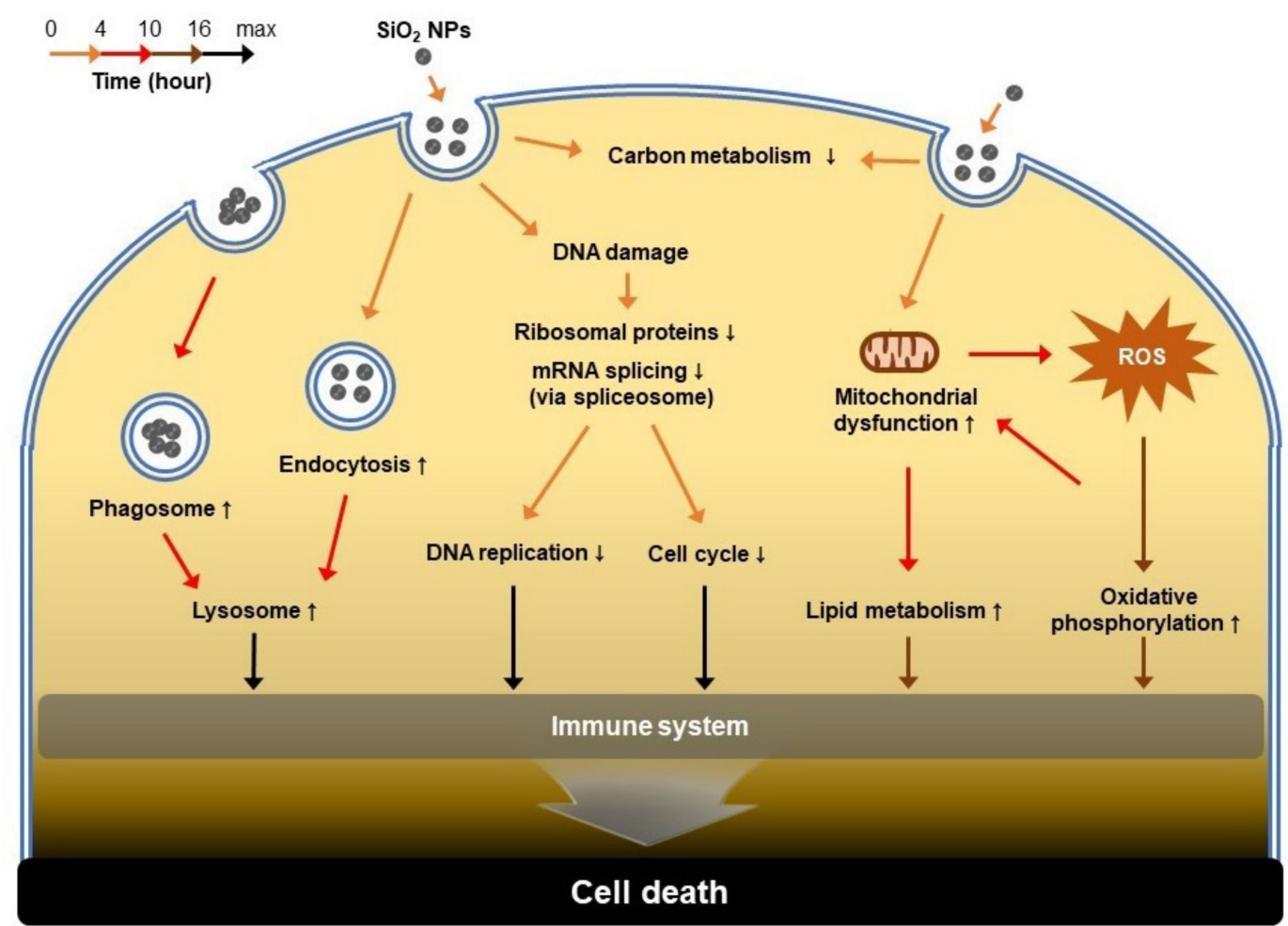

Figure 7. Mechanisms of $\mathrm{SiO}_{2} \mathrm{NP}$-induced cytotoxicity in HepG2 cells. The order of biological reactions that occur when $\mathrm{SiO}_{2} \mathrm{NPs}$ are exposed to cells is indicated by arrows. Orange, $4 \mathrm{~h}$; red, $10 \mathrm{~h}$; brown, $16 \mathrm{~h}$; black, after $16 \mathrm{~h}$. Responses observed in this study are indicated in bold letters, and those described through reference studies are indicated in light letters.

\section{Conclusions}

In this study, cytotoxicity was investigated in HepG2 cells according to the elapsed time $(0,4,10$, and $16 \mathrm{~h})$ of exposure to $\mathrm{SiO}_{2} \mathrm{NPs}$. Although the morphology of cells did not change at the early stages ( 0 to $4 \mathrm{~h}$ ), membrane damage at $4 \mathrm{~h}$ by LDH leakage assay was confirmed. To investigate a detailed mechanism of HepG2 cell responses through the uptake of $\mathrm{SiO}_{2} \mathrm{NPs}$, cells were harvested according to the above time intervals compared with cells not treated with $\mathrm{SiO}_{2} \mathrm{NPs}$, and proteomic analysis was performed using mass spectrometry. LFQ-based proteomic analysis results showed that $\mathrm{SiO}_{2} \mathrm{NPs}$ could be internalized into cells through several pathways, such as endocytosis and phagocytosis, resulting in an increase in the number of lysosomes. In addition, cell metabolism and cell division, such as mRNA splicing, cell cycle arrest, and mitochondrial dysfunction, already begin at $4 \mathrm{~h}$ after exposure to $\mathrm{SiO}_{2} \mathrm{NPs}$. ROS measurement using $\mathrm{H}_{2}$-DCF-DA staining showed a significant increase in ROS levels at $10 \mathrm{~h}$, which is consistent with the morphological changes. This finding suggests that DNA damage caused changes directly 
in HepG2 cells by $\mathrm{SiO}_{2}$ NPs rather than by ROS. By 10 to $16 \mathrm{~h}$, ROS activated intracellular oxidative phosphorylation and the immune system of HepG2 cells. These results explain the mechanism of hepatotoxicity following exposure to $\mathrm{SiO}_{2} \mathrm{NPs}$. The mass spectrometrybased proteomic approach has been suggested as a global evaluation method to confirm the cytotoxicity and biological effect of $\mathrm{SiO}_{2}$ NPs. This approach will also help to understand the cytotoxicity mechanisms of various nanomaterials.

Supplementary Materials: The following are available online at https:/ / www.mdpi.com/2218-273 X/11/3/375/s1, Figure S1: Determination of ROS levels in HepG2 cells over increase of exposure time $(0,4,10$, and $16 \mathrm{~h})$ to $\mathrm{SiO}_{2} \mathrm{NPs}$, Table S1: List of the exclusive proteins from HepG2 cells according to the exposure time of $\mathrm{SiO}_{2} \mathrm{NPs}$ by comparing the $0 \mathrm{~h}$ group, Table S2: List of downregulated proteins associated with protein-protein interaction networks (PPI) in Figure 4, Table S3: List of upregulated proteins associated with protein-protein interaction networks (PPI) in Figure 4.

Author Contributions: Conceptualization, S.Y.L., J.G.S., and T.G.L.; methodology, S.Y.L. and J.G.S.; validation, I.Y.K. and M.B.H.; investigation, S.Y.L. and J.G.S.; data curation, S.Y.L.; writing-original draft preparation, S.Y.L. and J.G.S.; writing-review and editing, T.G.L. and J.H.M.; supervision, T.G.L. and J.G.S. All authors have read and agreed to the published version of the manuscript.

Funding: The work was supported by the Development of Measurement Standards and Technology for Biomaterials and Medical Convergence (KRISS-2020-GP2020-0004) from the Korea Research Institute of Standards and Science and Nano Material Technology Development Program (NRF2016M3A7B6908929, NRF-2017M3A7B4041754, NRF-2018M3D1A1058814) of MSIP/NRF.

Institutional Review Board Statement: Not applicable.

Informed Consent Statement: Not applicable.

Data Availability Statement: All nanoLC-ESI-MS/MS raw data and PEAKS search result were deposited to the ProteomeXchange Consortium via the PRIDE partner repository with the dataset identifier PXD024206.

Conflicts of Interest: The authors declare no conflict of interest.

\section{References}

1. Li, L.; Tang, F.; Liu, H.; Liu, T.; Hao, N.; Chen, D.; Teng, X.; He, J. In vivo delivery of silica nanorattle encapsulated docetaxel for liver cancer therapy with low toxicity and high efficacy. ACS Nano 2010, 4, 6874-6882. [CrossRef] [PubMed]

2. Zhou, Y.; Quan, G.; Wu, Q.; Zhang, X.; Niu, B.; Wu, B.; Huang, Y.; Pan, X.; Wu, C. Mesoporous silica nanoparticles for drug and gene delivery. Acta Pharm. Sin. B 2018, 8, 165-177. [CrossRef] [PubMed]

3. Croissant, J.G.; Fatieiev, Y.; Almalik, A.; Khashab, N.M. Mesoporous silica and organosilica nanoparticles: Physical chemistry, biosafety, delivery strategies, and biomedical applications. Adv. Healthc. Mater. 2018, 7, 1700831. [CrossRef] [PubMed]

4. Fruijtier-Pölloth, C. The toxicological mode of action and the safety of synthetic amorphous silica-A nanostructured material. Toxicology 2012, 294, 61-79. [CrossRef] [PubMed]

5. Murugadoss, S.; Lison, D.; Godderis, L.; Van Den Brule, S.; Mast, J.; Brassinne, F.; Sebaihi, N.; Hoet, P.H. Toxicology of silica nanoparticles: An update. Arch. Toxicol. 2017, 91, 2967-3010. [CrossRef]

6. Oberdörster, G.; Maynard, A.; Donaldson, K.; Castranova, V.; Fitzpatrick, J.; Ausman, K.; Carter, J.; Karn, B.; Kreyling, W.; Lai, D.; et al. Principles for characterizing the potential human health effects from exposure to nanomaterials: Elements of a screening strategy. Part. Fibre Toxicol. 2005, 2, 8. [CrossRef]

7. Mohammadpour, R.; Yazdimamaghani, M.; Cheney, D.L.; Jedrzkiewicz, J.; Ghandehari, H. Subchronic toxicity of silica nanoparticles as a function of size and porosity. J. Control. Release 2019, 304, 216-232. [CrossRef]

8. Yu, T.; Greish, K.; McGill, L.D.; Ray, A.; Ghandehari, H. Influence of geometry, porosity, and surface characteristics of silica nanoparticles on acute toxicity: Their vasculature effect and tolerance threshold. ACS Nano 2012, 6, 2289-2301. [CrossRef]

9. Lu, X.; Qian, J.; Zhou, H.; Gan, Q.; Tang, W.; Lu, J.; Yuan, Y.; Liu, C. In vitro cytotoxicity and induction of apoptosis by silica nanoparticles in human HepG2 hepatoma cells. Int. J. Nanomed. 2011, 6, 1889-1901.

10. Lee, K.; Lee, J.; Kwak, M.; Cho, Y.L.; Hwang, B.; Cho, M.J.; Lee, N.G.; Park, J.; Lee, S.H.; Park, J.G.; et al. Two distinct cellular pathways leading to endothelial cell cytotoxicity by silica nanoparticle size. J. Nanobiotechnol. 2019, 17, 24. [CrossRef] [PubMed]

11. Duan, J.; Yu, Y.; Li, Y.; Yu, Y.; Li, Y.; Zhou, X.; Huang, P.; Sun, Z. Toxic effect of silica nanoparticles on endothelial cells through DNA damage response via Chk1-dependent G2/M checkpoint. PLoS ONE 2013, 8, e62087. [CrossRef] [PubMed]

12. Lesniak, A.; Fenaroli, F.; Monopoli, M.P.; Åberg, C.; Dawson, K.A.; Salvati, A. Effects of the presence or absence of a protein corona on silica nanoparticle uptake and impact on cells. ACS Nano 2012, 6, 5845-5857. [CrossRef] [PubMed] 
13. Rubio, L.; Pyrgiotakis, G.; Beltran-Huarac, J.; Zhang, Y.; Gaurav, J.; Deloid, G.; Spyrogianni, A.; Sarosiek, K.A.; Bello, D.; Demokritou, P. Safer-by-design flame-sprayed silicon dioxide nanoparticles: The role of silanol content on ROS generation, surface activity and cytotoxicity. Part. Fibre Toxicol. 2019, 16, 40. [CrossRef] [PubMed]

14. Nabeshi, H.; Yoshikawa, T.; Arimori, A.; Yoshida, T.; Tochigi, S.; Hirai, T.; Akase, T.; Nagano, K.; Abe, Y.; Hamada, H.; et al. Effect of surface properties of silica nanoparticles on their cytotoxicity and cellular distribution in murine macrophages. Nanoscale Res. Lett. 2011, 6, 1-6. [CrossRef]

15. Bhattacharjee, S.; de Haan, L.H.; Evers, N.M.; Jiang, X.; Marcelis, A.T.; Zuilhof, H.; Rietjens, I.M.C.M.; Alink, G.M. Role of surface charge and oxidative stress in cytotoxicity of organic monolayer-coated silicon nanoparticles towards macrophage NR8383 cells. Part. Fibre Toxicol. 2010, 7, 25. [CrossRef]

16. Goodman, C.M.; McCusker, C.D.; Yilmaz, T.; Rotello, V.M. Toxicity of gold nanoparticles functionalized with cationic and anionic side chains. Bioconjugate Chem. 2004, 15, 897-900. [CrossRef]

17. Oh, W.K.; Kim, S.; Choi, M.; Kim, C.; Jeong, Y.S.; Cho, B.R.; Hahn, J.S.; Jang, J. Cellular uptake, cytotoxicity, and innate immune response of silica - titania hollow nanoparticles based on size and surface functionality. ACS Nano 2010, 4, 5301-5313. [CrossRef]

18. Hozayen, W.G.; Mahmoud, A.M.; Desouky, E.M.; El-Nahass, E.S.; Soliman, H.A.; Farghali, A.A. Cardiac and pulmonary toxicity of mesoporous silica nanoparticles is associated with excessive ROS production and redox imbalance in Wistar rats. Biomed. Pharmacother. 2019, 109, 2527-2538. [CrossRef]

19. Yu, T.; Hubbard, D.; Ray, A.; Ghandehari, H. In vivo biodistribution and pharmacokinetics of silica nanoparticles as a function of geometry, porosity and surface characteristics. J. Control. Release 2012, 163, 46-54. [CrossRef] [PubMed]

20. Waegeneers, N.; Brasseur, A.; Van Doren, E.; Van der Heyden, S.; Serreyn, P.J.; Pussemier, L.; Mast, J.; Schneider, Y.J.; Ruttens, A.; Roels, S. Short-term biodistribution and clearance of intravenously administered silica nanoparticles. Toxicol. Rep. 2018, 5, 632-638. [CrossRef]

21. Duan, J.; Liang, S.; Feng, L.; Yu, Y.; Sun, Z. Silica nanoparticles trigger hepatic lipid-metabolism disorder in vivo and in vitro. Int. J. Nanomed. 2018, 13, 7303-7318. [CrossRef] [PubMed]

22. Yu, Y.; Duan, J.; Li, Y.; Li, Y.; Jing, L.; Yang, M.; Wang, J.; Sun, Z. Silica nanoparticles induce liver fibrosis via TGF- $\beta 1 /$ Smad3 pathway in ICR mice. Int. J. Nanomed. 2017, 12, 6045-6057. [CrossRef] [PubMed]

23. Yu, Y.; Li, Y.; Wang, W.; Jin, M.; Du, Z.; Li, Y.; Duan, J.; Yu, Y.; Sun, Z. Acute toxicity of amorphous silica nanoparticles in intravenously exposed ICR mice. PLoS ONE 2013, 8, e61346. [CrossRef] [PubMed]

24. Akhtar, M.J.; Ahamed, M.; Kumar, S.; Siddiqui, H.; Patil, G.; Ashquin, M.; Ahmad, I. Nanotoxicity of pure silica mediated through oxidant generation rather than glutathione depletion in human lung epithelial cells. Toxicology 2010, 276, 95-102. [CrossRef]

25. Kim, I.Y.; Joachim, E.; Choi, H.; Kim, K. Toxicity of silica nanoparticles depends on size, dose, and cell type. Nanomedicine 2015, 11, 1407-1416. [CrossRef]

26. Sun, L.; Li, Y.; Liu, X.; Jin, M.; Zhang, L.; Du, Z.; Guo, C.; Huang, P.; Sun, Z. Cytotoxicity and mitochondrial damage caused by silica nanoparticles. Toxicol. In Vitro 2011, 25, 1619-1629. [CrossRef]

27. Chen, Q.; Xue, Y.; Sun, J. Kupffer cell-mediated hepatic injury induced by silica nanoparticles in vitro and in vivo. Int. J. Nanomed. 2013, 8, 1129-1140.

28. Hillegass, J.M.; Shukla, A.; Lathrop, S.A.; MacPherson, M.B.; Fukagawa, N.K.; Mossman, B.T. Assessing nanotoxicity in cells in vitro. Wiley Interdiscip. Rev. Nanomed. Nanobiotechnol. 2010, 2, 219-231. [CrossRef]

29. Yu, T.; Malugin, A.; Ghandehari, H. Impact of silica nanoparticle design on cellular toxicity and hemolytic activity. ACS Nano 2011, 5, 5717-5728. [CrossRef]

30. Kim, W.; Kim, W.K.; Lee, K.; Son, M.J.; Kwak, M.; Chang, W.S.; Min, J.K.; Song, N.W.; Lee, J.; Bae, K.H. A reliable approach for assessing size-dependent effects of silica nanoparticles on cellular internalization behavior and cytotoxic mechanisms. Int. J. Nanomed. 2019, 14, 7375-7387. [CrossRef]

31. Park, M.V.; Annema, W.; Salvati, A.; Lesniak, A.; Elsaesser, A.; Barnes, C.; McKerr, G.; Howard, C.V.; Lynch, I.; Dawson, K.A.; et al. In vitro developmental toxicity test detects inhibition of stem cell differentiation by silica nanoparticles. Toxicol. Appl. Pharmacol. 2009, 240, 108-116. [CrossRef]

32. Passagne, I.; Morille, M.; Rousset, M.; Pujalté, I.; L'azou, B. Implication of oxidative stress in size-dependent toxicity of silica nanoparticles in kidney cells. Toxicology 2012, 299, 112-124. [CrossRef]

33. Lai, Z.W.; Yan, Y.; Caruso, F.; Nice, E.C. Emerging techniques in proteomics for probing nano-bio interactions. ACS Nano 2012, 6 , 10438-10448. [CrossRef] [PubMed]

34. Othman, Z.; Pastor, B.C.; van Rijt, S.; Habibovic, P. Understanding interactions between biomaterials and biological systems using proteomics. Biomaterials 2018, 167, 191-204. [CrossRef]

35. Zhang, T.; Gaffrey, M.J.; Thomas, D.G.; Weber, T.J.; Hess, B.M.; Weitz, K.K.; Piehowski, P.D.; Petyuk, V.A.; Moore, R.J.; Qian, W.J.; et al. A proteome-wide assessment of the oxidative stress paradigm for metal and metal-oxide nanomaterials in human macrophages. NanoImpact 2020, 17, 100194. [CrossRef] [PubMed]

36. Lee, S.Y.; Son, J.G.; Moon, J.H.; Joh, S.; Lee, T.G. Comparative study on formation of protein coronas under three different serum origins. Biointerphases 2020, 15, 061002. [CrossRef] [PubMed]

37. Feifel, S.C.; Lisdat, F. Silica nanoparticles for the layer-by-layer assembly of fully electro-active cytochrome c multilayers. J. Nanobiotechnology 2011, 9, 1-12. [CrossRef] [PubMed] 
38. D'Arienzo, M.; Dirè, S.; Cobani, E.; Orsini, S.; Di Credico, B.; Antonini, C.; Callone, E.; Parrino, F.; Vacche, S.D.; Trusiano, G.; et al. $\mathrm{SiO}_{2}$ /Ladder-Like Polysilsesquioxanes Nanocomposite Coatings: Playing with the Hybrid Interface for Tuning Thermal Properties and Wettability. Coatings 2020, 10, 913. [CrossRef]

39. Jiang, L.; Yu, Y.; Li, Y.; Yu, Y.; Duan, J.; Zou, Y.; Li, Q.; Sun, Z. Oxidative damage and energy metabolism disorder contribute to the hemolytic effect of amorphous silica nanoparticles. Nanoscale Res. Lett. 2016, 11, 57. [CrossRef]

40. Kusaczuk, M.; Krętowski, R.; Naumowicz, M.; Stypułkowska, A.; Cechowska-Pasko, M. Silica nanoparticle-induced oxidative stress and mitochondrial damage is followed by activation of intrinsic apoptosis pathway in glioblastoma cells. Int. J. Nanomed. 2018, 13, 2279-2294. [CrossRef]

41. Guo, C.; Xia, Y.; Niu, P.; Jiang, L.; Duan, J.; Yu, Y.; Zhou, X.; Li, Y.; Sun, Z. Silica nanoparticles induce oxidative stress, inflammation, and endothelial dysfunction in vitro via activation of the MAPK/Nrf2 pathway and nuclear factor-kB signaling. Int. J. Nanomed. 2015, 10, 1463-1477. [CrossRef]

42. de Boer, H.R.; Llobet, S.G.; van Vugt, M.A. Controlling the response to DNA damage by the APC/C-Cdh1. Cell. Mol. Life Sci. 2016, 73, 949-960. [CrossRef] [PubMed]

43. Guo, C.; Wang, J.; Jing, L.; Ma, R.; Liu, X.; Gao, L.; Cao, L.; Duan, J.; Zhou, X.; Li, Y.; et al. Mitochondrial dysfunction, perturbations of mitochondrial dynamics and biogenesis involved in endothelial injury induced by silica nanoparticles. Environ. Pollut. 2018, 236, 926-936. [CrossRef]

44. Liu, J.; Li, X.; Zhou, G.; Sang, Y.; Zhang, Y.; Zhao, Y.; Ge, W.; Sun, Z.; Zhou, X. Silica nanoparticles induce spermatogenesis disorders via L3MBTL2-DNA damage-p53 apoptosis and RNF8-ubH2A/ubH2B pathway in mice. Environ. Pollut. 2020, 265, 114974. [CrossRef]

45. Kaya, N.; Çakmak, I.; Akarsu, E.; Kaya, B. DNA damage induced by silica nanoparticle. Fresenius Environ. Bull. 2015, 24, 4478-4484.

46. Mu, Q.; Hondow, N.S.; Krzemiński, Ł.; Brown, A.P.; Jeuken, L.J.; Routledge, M.N. Mechanism of cellular uptake of genotoxic silica nanoparticles. Part. Fibre Toxicol. 2012, 9, 29. [CrossRef] [PubMed]

47. Wang, J.; Yu, Y.; Lu, K.; Yang, M.; Li, Y.; Zhou, X.; Sun, Z. Silica nanoparticles induce autophagy dysfunction via lysosomal impairment and inhibition of autophagosome degradation in hepatocytes. Int. J. Nanomed. 2017, 12, 809-825. [CrossRef] [PubMed]

48. Deng, Y.D.; Zhang, X.D.; Yang, X.S.; Huang, Z.L.; Wei, X.; Yang, X.F.; Liao, W.Z. Subacute toxicity of mesoporous silica nanoparticles to the intestinal tract and the underlying mechanism. J. Hazard Meter. 2020, 13, 124502. [CrossRef]

49. Mohamed, B.M.; Verma, N.K.; Prina-Mello, A.; Williams, Y.; Davies, A.M.; Bakos, G.; Tormey, L.; Edwards, C.; Hanrahan, J.; Salvati, A.; et al. Activation of stress-related signalling pathway in human cells upon $\mathrm{SiO}_{2}$ nanoparticles exposure as an early indicator of cytotoxicity. J. Nanobiotechnology 2011, 9, 29. [CrossRef]

50. Stern, S.T.; Adiseshaiah, P.P.; Crist, R.M. Autophagy and lysosomal dysfunction as emerging mechanisms of nanomaterial toxicity. Part. Fibre Toxicol. 2012, 9, 20. [CrossRef]

51. Rathore, B.; Sunwoo, K.; Jangili, P.; Kim, J.; Kim, J.H.; Huang, M.; Xiong, J.; Sharma, A.; Yang, Z.; Qu, J.; et al. Nanomaterial designing strategies related to cell lysosome and their biomedical applications: A review. Biomaterials 2019, 211, 25-47. [CrossRef]

52. Manzanares, D.; Ceña, V. Endocytosis: The Nanoparticle and Submicron Nanocompounds Gateway into the Cell. Pharmaceutics 2020, 12, 371. [CrossRef]

53. Shkreta, L.; Chabot, B. The RNA splicing response to DNA damage. Biomolecules 2015, 5, 2935-2977. [CrossRef] [PubMed]

54. Chen, J.; Crutchley, J.; Zhang, D.; Owzar, K.; Kastan, M.B. Identification of a DNA Damage-Induced Alternative Splicing Pathway That Regulates p53 and Cellular Senescence Markers. Cancer Discov. 2017, 7, 766-781. [CrossRef] [PubMed]

55. Nabeshi, H.; Yoshikawa, T.; Matsuyama, K.; Nakazato, Y.; Tochigi, S.; Kondoh, S.; Hirai, T.; Akase, T.; Nagano, K.; Abe, Y.; et al Amorphous nanosilica induce endocytosis-dependent ROS generation and DNA damage in human keratinocytes. Part. Fibre Toxicol. 2011, 8, 1. [CrossRef]

56. Li, Y.; Sun, L.; Jin, M.; Du, Z.; Liu, X.; Guo, C.; Li, Y.; Huang, P.; Sun, Z. Size-dependent cytotoxicity of amorphous silica nanoparticles in human hepatoma HepG2 cells. Toxicol. In Vitro 2011, 25, 1343-1352. [CrossRef]

57. Wang, F.; Gao, F.; Lan, M.; Yuan, H.; Huang, Y.; Liu, J. Oxidative stress contributes to silica nanoparticle-induced cytotoxicity in human embryonic kidney cells. Toxicol. In Vitro 2009, 23, 808-815. [CrossRef]

58. Shin, T.H.; Seo, C.; Ji, M.; Manavalan, B.; Basith, S.; Chakkarapani, S.K.; Kang, S.H.; Lee, G.; Paik, M.J.; Park, C.B. Silica-coated magnetic nanoparticles induce glucose metabolic dysfunction in vitro via the generation of reactive oxygen species. Arch. Toxicol. 2019, 93, 1201-1212. [CrossRef] [PubMed]

59. Shim, W.; Paik, M.J.; Nguyen, D.T.; Lee, J.K.; Lee, Y.; Kim, J.H.; Shin, E.H.; Kang, J.S.; Jung, H.S.; Choi, S.; et al. Analysis of changes in gene expression and metabolic profiles induced by silica-coated magnetic nanoparticles. ACS Nano 2012, 6, 7665-7680. [CrossRef]

60. Yu, Y.; Duan, J.; Yu, Y.; Li, Y.; Liu, X.; Zhou, X.; Ho, K.F.; Tian, L.; Sun, Z. Silica nanoparticles induce autophagy and autophagic cell death in HepG2 cells triggered by reactive oxygen species. J. Hazard. Mater. 2014, 270, 176-186. [CrossRef]

61. Krętowski, R.; Kusaczuk, M.; Naumowicz, M.; Kotyńska, J.; Szynaka, B.; Cechowska-Pasko, M. The effects of silica nanoparticles on apoptosis and autophagy of glioblastoma cell lines. Nanomaterials 2017, 7, 230. [CrossRef] [PubMed]

62. Ahamed, M. Silica nanoparticles-induced cytotoxicity, oxidative stress and apoptosis in cultured A431 and A549 cells. Hum. Exp. Toxicol. 2013, 32, 186-195. [CrossRef] [PubMed] 
63. Yang, Y.; Du, X.; Wang, Q.; Liu, J.; Zhang, E.; Sai, L.; Peng, C.; Lavin, M.F.; Yeo, A.J.; Yang, X.; et al. Mechanism of cell death induced by silica nanoparticles in hepatocyte cells is by apoptosis. Int. J. Mol. Med. 2019, 44, 903-912. [CrossRef]

64. Niu, Y.; Tang, E.; Zhang, Q. Cytotoxic effect of silica nanoparticles against hepatocellular carcinoma cells through necroptosis induction. Toxicol. Res. 2019, 8, 1042-1049. [CrossRef] [PubMed] 